IZA DP No. 4400

Do Better Paid Politicians Perform Better?

Disentangling Incentives from Selection

Stefano Gagliarducci

Tommaso Nannicini

September 2009 


\title{
Do Better Paid Politicians Perform Better? Disentangling Incentives from Selection
}

\author{
Stefano Gagliarducci \\ Tor Vergata University \\ and IZA
Tommaso Nannicini
Bocconi University, IGIER
and IZA

\section{Discussion Paper No. 4400 \\ September 2009}

\author{
IZA \\ P.O. Box 7240 \\ 53072 Bonn \\ Germany \\ Phone: +49-228-3894-0 \\ Fax: +49-228-3894-180 \\ E-mail: iza@iza.org
}

\begin{abstract}
Any opinions expressed here are those of the author(s) and not those of IZA. Research published in this series may include views on policy, but the institute itself takes no institutional policy positions.

The Institute for the Study of Labor (IZA) in Bonn is a local and virtual international research center and a place of communication between science, politics and business. IZA is an independent nonprofit organization supported by Deutsche Post Foundation. The center is associated with the University of Bonn and offers a stimulating research environment through its international network, workshops and conferences, data service, project support, research visits and doctoral program. IZA engages in (i) original and internationally competitive research in all fields of labor economics, (ii) development of policy concepts, and (iii) dissemination of research results and concepts to the interested public.
\end{abstract}

IZA Discussion Papers often represent preliminary work and are circulated to encourage discussion. Citation of such a paper should account for its provisional character. A revised version may be available directly from the author. 
IZA Discussion Paper No. 4400

September 2009

\section{ABSTRACT}

\section{Do Better Paid Politicians Perform Better? Disentangling Incentives from Selection}

The wage paid to politicians affects both the choice of citizens to run for an elective office and the performance of those who are appointed. First, if skilled individuals shy away from politics because of higher opportunities in the private sector, an increase in politicians' pay may change their mind. Second, if the reelection prospects of incumbents depend on their inoffice deeds, a higher wage may foster performance. We use data on all Italian municipal governments from 1993 to 2001 and test these hypotheses in a quasi-experimental framework. In Italy, the wage of the mayor depends on population size and sharply rises at different thresholds. We apply a regression discontinuity design to the only threshold that uniquely identifies a wage increase - 5,000 inhabitants - to control for unobservable town characteristics. Exploiting the existence of a two-term limit, we further disentangle the composition from the incentive component of the effect of the wage on performance. Our results show that a higher wage attracts more educated candidates, and that better paid politicians size down the government machinery by improving internal efficiency. Importantly, most of this performance effect is driven by the selection of competent politicians, rather than by the incentive to be reelected.

JEL Classification: $\quad$ M52, D72, J45, H70

Keywords: political selection, efficiency wage, term limit, local finance, regression discontinuity design

Corresponding author:

Tommaso Nannicini

Department of Economics

Bocconi University

Via Roentgen 1

20136 Milan

Italy

E-mail: tommaso.nannicini@unibocconi.it

\footnotetext{
*We thank Alberto Alesina, Marianne Bertrand, Stéphane Bonhomme, Michael Elsby, Nicola Persico, Steve Pischke, Albert Solé, and seminar participants at Universitat de Barcelona, CEMFI, ESSLECEPR 2008, IMT Lucca, IGIER-Bocconi, and SOLE 2009 for their insightful comments. We are also grateful to Fabio Albiani from the Italian Ministry of Internal Affairs for invaluable help with data collection, and to Lucia Spadaccini for excellent research assistance. The usual caveat applies.
} 


\section{Introduction}

Paying politicians is a debated but elusive topic. Firms set the wage of workers to maximize their profits; politicians set the wage of bureaucrats to maximize either social welfare or their own interests. For the same reason, citizens - the principal - should set the optimal compensation of politicians - the agent-according to some welfare criteria. But this is rarely the case. The wage of elected officials is decided by politicians themselves. And the public opinion swings from the complaint against the high salaries of the political elite to the acknowledgment that "if you pay peanuts you get monkeys" also in politics. ${ }^{1}$ No evidence unambiguously supports either claim.

The wage paid to elected officials is an important element - although not the only onein shaping both the decision to enter politics and the behavior once in office. According to the standard efficiency wage theory, a salary increase could both attract more skilled candidates (citizens with higher opportunity costs) and enhance performance (because of the higher cost of not being reelected). Various models in political economics contain similar intuitions while adding more structure on the political side - see, among others, Besley (2004) and Caselli and Morelli (2004). Alternative models, instead, build on some peculiarities of the political sector to show that, if high-skilled citizens have a comparative advantage in entering politics - for instance, because of higher post-congressional returns, as in Mattozzi and Merlo (2008) - paying politicians more may have a crowding-out effect and decrease the average quality. At the end of the day, the question of whether politicians' remuneration affects their selection and performance remains empirical.

In this paper, we use a dataset on the mayors of all Italian municipalities from 1993 to 2001 to evaluate the impact of politicians' remuneration in a quasi-experimental framework. In Italy, the wage of the mayor increases with the size of the resident population, the motivation for this rule being that, as for companies' executives, the amount of work and responsibility grows with the number of people to be managed. The quasi-experimental framework arises because the wage does not increase monotonically, but sharply changes at nine different thresholds. As long as population size cannot be manipulated by the

\footnotetext{
${ }^{1}$ Other traditional views emphasize that a better pay might also guarantee a broader representation of all social categories, and reduce the incentives for corruption. We focus here on competence and performance, because other measures of politicians' quality, such as honesty, are not available.
} 
mayor to sort above these thresholds and be paid more, the institutional setting delivers a clean exogenous variation in the remuneration of politicians. This is not the case with other observational setups, which are plagued with sizable selection bias if politicians can set their own wage, or if environmental characteristics influence both the salary and the opportunity cost of entering politics.

Politicians' pay is not the only policy decided by the number of resident inhabitants, though. The size of the municipal council, the electoral rule, and many other policies vary according to population brackets. After inquiring the Ministry of Internal Affairs and comparing different legislative sources as a cross-check, we found out that only three thresholds uniquely identify a wage increase: 1,000, 5,000, and 50,000 inhabitants. However, we cannot use the 1,000 threshold because of its late introduction (in 2000) and the 50,000 threshold because of sample size limitations. We hence focus on the 5,000 threshold, at which there is a sharp $33 \%$ increase (28\% after 2000) in the mayor's wage. Although the local effect identified at this threshold may not be easily generalized to higher population levels, it should be noted that small cities (below 10,000 inhabitants) account for about $90 \%$ of all Italian municipalities. Furthermore, the large executive power of mayors, and the close monitoring put forth by voters especially in small municipalities, fit well with Besley's (2004, p. 210) recommendation that agency models on paying politicians "are most promising when applied in situations where there are directly elected chief executives with significant discretionary power." We therefore apply a Regression Discontinuity Design (RDD) at the 5,000 threshold to control for unobservable town characteristics and test whether a higher wage attracts individuals with higher opportunity costs (effect of the wage on political selection) and improves the performance of elected politicians (effect of the wage on performance).

As for selection, the empirical results show that the $33 \%$ wage increase at 5,000 attracts more educated candidates: from 0.9 to 1.2 years of schooling more, depending on the specification, which means an increase in education from $6.4 \%$ to $8.6 \%$ (with respect to an average of 14 years of schooling in municipalities between 3,000 and 5,000 inhabitants). There is also evidence that the wage increase attracts more candidates employed in highskilled occupations, such as lawyers, professionals, or entrepreneurs. This translates into more educated (from 0.9 to 1.6 years of schooling more) and high-skilled elected mayors. 
As for performance, following the literature on political accountability and political budget cycles, we first look at policies of direct interest to voters, such as taxes, tariffs, and expenditures. ${ }^{2}$ We find that better paid politicians reduce the size of the municipal government. In particular, they lower taxes and tariffs per capita (by about $13 \%$ and $86 \%$, respectively) and reduce the amount of personnel and other current expenditures (by about $11 \%$ and $22 \%$, respectively).

This performance result can have two different interpretations. First, more skilled politicians are better at making the government machinery more efficient, as they reduce current - instead of capital - expenditure, characterized by sizable passive waste in Italy (Bandiera, Prat, and Valletti, 2009). Second, the reduction in government size reflects differences in preferences, with more educated mayors having weaker preferences for redistribution and public services (Alesina and Giuliano, 2009). We shed more light on these alternative explanations by looking at two efficiency indicators for the management of the municipal government: the speed of revenues collection (that is, the ratio between collected and assessed revenues) and the speed of payment (that is, the ratio between paid and committed outlays). Our results show that better paid mayors effectively increase the speed of revenues collection by $7 \%$. And this supports the interpretation that they are at least able to make the bureaucratic organization more efficient.

The effect of the wage on performance might be driven by two distinct components: better paid politicians may act differently because of their higher skills (composition effect of the wage on performance) or because of enhanced reelection motives (incentive effect of the wage on performance). ${ }^{3}$ To disentangle these two channels, we exploit another institutional feature of the Italian legislation: the existence of a two-term limit. It is true, indeed, that also mayors with a binding term limit have a lot of incentives to perform well, including the desire to run for higher offices or to leave a positive legacy, but all of these motivations do not depend on the wage. Therefore, mayors just below and just above the 5,000 threshold have identical incentives when they all face a binding term limit. On the contrary, when the term limit is not binding, their incentives diverge because of the

\footnotetext{
${ }^{2}$ As empirical tests of political agency models using budget variables, see - among others - Besley and Case (1995) and List and Sturm (2006). As empirical studies on political budget cycles, see - among others-Akhmedov and Zhuravskaja (2004) and Brender and Drazen (2008).

${ }^{3}$ To avoid confusion between terms, we refer to "selection effect" as the impact of the wage on selection, and to "composition effect" as the selection component of the impact of the wage on performance.
} 
different wage they would obtain if reelected. Following a diff-in-diff strategy, we thus subtract the difference between the performance of second-term mayors just above and below the threshold from the difference between the performance of first-term mayors just above and below the threshold, to retrieve an estimate of the (reelection) incentive effect of the wage on performance. Our results show that most of the performance effect is driven by the higher competence of the elected mayors, rather than by the incentive to be reelected. We take this as evidence of the strength of the composition effect. Alternative explanations for the lack of a (reelection) incentive effect, including strong ideological preferences by voters, do not receive support from the data.

The paper proceeds as follows. In Section 2, we set the theoretical background and review the related literature. In Section 3, we formalize our econometric strategy. In Section 4, we describe the institutional framework and the data. In Section 5, we present the estimation results and a number of robustness exercises. We conclude with Section 6 .

\section{Related literature}

\subsection{Theoretical background}

According to the efficiency wage theory, workers' productivity is increasing in the real wage they are paid. ${ }^{4}$ There are three main explanations for why this relationship should hold: paying workers more reduces shirking because of the higher cost of being fired (Shapiro and Stiglitz, 1984); it enhances the quality of applicants (Weiss, 1980); and it improves motivation and group work norms (Akerlof, 1982). If we apply these insights to the labor market for politicians, we should conclude that a higher wage is likely to improve the performance of elected officials due to different reasons. First, a higher wage will attract more skilled individuals (that is, citizens with better outside opportunities in the private sector) into politics. Second, it will increase the incumbent's payoff from being reelected; and this, in turn, will make elected officials more disciplined (e.g., less inclined to extract rents). Third, it could improve the morale of politicians.

The efficiency wage theory, of course, does not consider many aspects that are specific to the political arena, such as party selection, campaigning, non-monetary incentives, and

\footnotetext{
${ }^{4}$ See Akerlof and Yellen (1986) or Yellen (1984) for a survey of the efficiency wage literature.
} 
voters' preferences. Various models in political economics, however, contain some intuitions and predictions of the efficiency wage theory while providing specific insights on the political side. Besley (2004) builds an agency model with both unobserved heterogeneity in the congruence of politicians with voters (adverse selection) and unobserved action when in office (moral hazard). As reelection is the main incentive mechanism, a higher wage plays a discipline role, that is, it increases performance by forcing dissonant politicians to extract lower rents. Moreover, a higher wage also increases the fraction of congruent politicians, who - unlike the dissonant type - earn no rents from entering politics. Caselli and Morelli (2004) present an adverse selection model where low-quality citizens ("bad politicians") have a comparative advantage in holding office, because their market wages are lower than those of more competent individuals, or because they extract more rents than more honest individuals. In this framework, a higher salary raises the average quality of the (self-selected) pool of politicians. Persson and Tabellini (2000) propose a careerconcern model where forward-looking voters use past performance to estimate the ability of the incumbent. As a result, also low-ability officials have an incentive to cut rents and increase the political output in order to be reelected. In this framework, the higher the wage, the lower politicians' rents and the higher performance.

The prediction that the quality of politicians is increasing in their wage, however, is not unanimously shared by the literature. Actually, a number of models suggest that the opposite may be true in all the circumstances in which high-quality citizens have other incentives to enter politics, because a higher remuneration has the indirect effect of making all the other (low-quality) candidates more willing to run. ${ }^{5}$ For example, Mattozzi and Merlo (2008) propose a dynamic model where there are both "career politicians," who stay in politics until retirement, and individuals with "political careers," who stay in politics for a while in order to signal their true ability to the private sector. In this framework, a wage increase lowers the average quality of citizens who have political careers, because politics becomes a relatively more attractive option for all levels of skills, and it has an ambiguous effect on the average quality of career politicians, because also high-ability incumbents are more willing to remain in politics. Gagliarducci, Nannicini, and Naticchioni (2008)

\footnotetext{
${ }^{5}$ Messner and Polborn (2004) come to a similar conclusion, although in their case the rationale is that competent candidates have an higher incentive to free-ride on mediocre candidates, under the assumption that the attractiveness of public life is low.
} 
study the effect of outside income on political selection: if politicians can keep their private business while appointed and election boosts the private returns of high-ability citizens, then outside income can induce equilibria with positive sorting, where a wage increase would make the public office relatively more attractive for low-ability citizens. Finally, Besley (2005) introduces another explanation of the negative impact of the wage on politicians' quality: if public service motivations are strong, a higher remuneration lowers the relative attractiveness of politics for public-spirited individuals.

\section{$2.2 \quad$ Empirical studies}

Despite this rich set of theoretical predictions, there are only a few empirical studies on the impact of politicians' remuneration. Di Tella and Fisman (2004) look at gubernatorial pay in the US from 1950 to 1990 and find that wages respond to changes in state income and taxes per capita. In particular, governors obtain a one percent pay cut for each ten percent increase in per capita taxation, and there is some evidence that this negative tax elasticity is an implicit form of performance pay. Besley (2004) analyzes the same data on US gubernatorial pay. He finds that the congruence between the ideological positions of the governor and citizens - as measured by established surveys - is positively associated with the governor's wage. Diermeier, Keane, and Merlo (2005) estimate a structural dynamic model of congressional careers in the US, finding that congressional experience significantly increases post-congressional wages in the private sector. Keane and Merlo (2007) use the same model to evaluate the effect of reducing the relative wage of congressmen. They find that a wage reduction would induce more skilled politicians to exit Congress (where skills refer to the ability to win elections), but this is not true for "achievers," that is, for those who perform better in terms of legislative and policy goals.

An empirical exercise similar to ours was presented, independently, by Ferraz and Finan (2009). To the best of our knowledge, this is the only other paper that builds on a clean exogenous variation in the pay of elected officials. They implement an RDD exploiting a Brazilian constitutional amendment that introduced caps on the wages of municipal councillors (vereadores) according to population size. They show that a higher wage attracts more candidates and, in particular, more educated ones; they also find that legislative productivity — measured as the number of bills submitted and approved- 
increases with the salary. Despite the similarity between the two approaches, however, our paper is distinct in many respects. First, we implement a sharp (instead of a fuzzy) RDD, because in Italy it is the statutory wage that varies with population size. Second, we focus on the mayor as the chief executive of the municipality, and then we look at budget indicators as performance outcomes. Third - and most important - we disentangle between the composition and the incentive effect of the wage on performance, exploiting the existence of a two-term limit.

To a lower extent, our paper also relates to other strands of the political economics literature. Recent studies have implemented RDD exercises based on policies that vary with population size at the local level, in order to estimate the effect of the number of legislators on the size of government (Petterson-Lindbom, 2008), the effect of the electoral rule on economic policy (Bordignon and Tabellini, 2008; Chamon et al., 2008), the effect of fiscal windfalls on corruption and political selection (Brollo et al., 2009), or the effect of direct versus representative democracy (Petterson-Lindbom and Tyrefors, 2009). Our results could also be compared with the studies on the effect of civil servants' pay on corruption (Besley and McLaren, 1993; Van Rijckeghem and Weder, 2001), although we look at elected officials and focus on administrative IQ rather than honesty. Finally, as we make the assumption that a binding term limit wipes out reelection incentives, we borrow insights from the vast literature on political accountability and term limits. ${ }^{6}$

\section{Econometric framework}

\subsection{Identifying the effect of the wage}

In this section, we formalize the evaluation framework that allows us to identify the effect of the wage on both the selection and the in-office performance of politicians. In particular, we want to test the following hypotheses.

(1ㅡ) A higher wage attracts more citizens with high opportunity costs into politics, that is, more skilled individuals with high alternative remunerations in the private sector (effect of the wage on political selection).

\footnotetext{
${ }^{6}$ See - among others - Rogoff (1990), Besley and Case (1995), Maskin and Tirole (2004), List and Sturm (2006), Smart and Sturm (2006), and Ferraz and Finan (2007).
} 
(느) A higher wage enhances the performance of elected officials (effect of the wage on performance). This may in turn be determined by two channels:

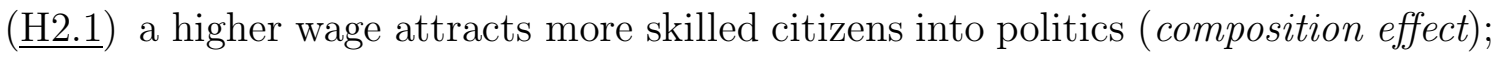

$(\underline{\mathrm{H} 2.2})$ a higher wage increases the cost of not being reelected (incentive effect).

A major empirical difficulty in identifying the effect of politicians' remuneration on their selection and performance is the absence of a truly exogenous variation in the amount they are paid. It is not hard to imagine rent-seeking politicians raising their own salary, or righteous representatives giving up part of their remuneration to prove their publicspiritedness. For the same reason, in the absence of an exogenous rule, one might also expect the social environment (e.g., the level of economic development, social capital, or corruption) to determine both politicians' wage and characteristics. To overcome these endogeneity problems, we exploit the Italian policy of paying mayors according to the population size of the municipality.

Define $X_{i}$ as the characteristics of citizens who run for mayor in town $i$; $Y_{i}$ as some performance indicator; $P_{i}$ as the population size; and $W_{i}$ as the wage paid to the mayor. By law, the wage sharply increases at the population threshold $P_{c}$. That is, if $P_{i} \geq P_{c}$, then $W_{i}=W_{h}$; if $P_{i}<P_{c}$, then $W_{i}=W_{\ell}<W_{h}$. To formalize the idea that both the characteristics of politicians and the performance of the mayor depend on the wage, we use a potential outcome framework. Define $X_{i}\left(W_{k}\right) \equiv X_{i k}$, with $k \in\{\ell, h\}$, as the potential characteristics of politicians in town $i$ if the wage is equal to $W_{k}$. Similarly, $Y_{i}\left(W_{k}\right) \equiv Y_{i k}$, with $k \in\{\ell, h\}$, captures the potential performance of the mayor in town $i$ if the wage is equal to $W_{k}$. In the following, we omit the subscript $i$, for all variables are town-specific.

For each town, we either observe $X_{\ell}$ and $Y_{\ell}$ or $X_{h}$ and $Y_{h}$, according to the wage of the mayor. The estimand of interest is the average treatment effect for the entire population or for a subpopulation of cities $(\Omega): E\left[X_{h}-X_{\ell} \mid i \in \Omega\right]$ and $E\left[Y_{h}-Y_{\ell} \mid i \in \Omega\right]$. The conditional comparison of $X$ and $Y$ in towns with $W=W_{\ell}$ against towns with $W=W_{h}$ does not generally provide an unbiased estimate of the average treatment effect, because towns with different unobservable characteristics may endogenously choose the mayor's remuneration, as discussed above. The fact that in Italy the salary of mayors depends on the population size, however, can be exploited to implement a sharp RDD and estimate 
the causal effect of the wage on both $X$ and $Y$. In order to do this, we need to make the following assumptions. ${ }^{7}$

Assumption $1 E\left[X_{\ell} \mid P=p\right]$ and $E\left[X_{h} \mid P=p\right]$ are continuous in $p$ at $P_{c}$.

Assumption $2 E\left[Y_{\ell} \mid P=p\right]$ and $E\left[Y_{h} \mid P=p\right]$ are continuous in $p$ at $P_{c}$.

In other words, the potential characteristics of the political elite and the potential performance of the mayor, which may depend on the population size $P$, should not display any discontinuity at $P_{c}$. Although both assumptions are more than plausible in our setting, two caveats are in order. First, if mayors can manipulate population size and sort above the threshold, treatment assignment is no longer exogenous. Second, if there is another policy that depends on population size and shares the same threshold $P_{c}$, the effect of the wage is confounded with the effect of this other policy and cannot be identified. It is thus important to check whether the data provide evidence of sorting around the threshold, and to be sure that other policies do not vary across the same population threshold.

Under Assumption 1, it is straightforward to show that $E\left[X_{\ell} \mid P=P_{c}\right]=\lim _{P \uparrow P_{c}} X$ and $E\left[X_{h} \mid P=P_{c}\right]=\lim _{P \downarrow P_{c}} X$. We can thus identify the treatment effect of the wage on political selection as

$$
\tau_{s e l} \equiv E\left[X_{h}-X_{\ell} \mid P=P_{c}\right]=\lim _{P \downarrow P_{c}} X-\lim _{P \uparrow P_{c}} X
$$

Similarly, under Assumption 2, the treatment effect of the wage on performance is

$$
\tau_{p e r} \equiv E\left[Y_{h}-Y_{\ell} \mid P=P_{c}\right]=\lim _{P \downarrow P_{c}} Y-\lim _{P \uparrow P_{c}} Y .
$$

Both $\tau_{\text {sel }}$ and $\tau_{\text {per }}$ are defined as local effects, because they capture the impact of the wage only for towns around the threshold $P_{c}$. As usual in RDD, the gain in internal validity comes at the price of lower external validity.

\subsection{Disentangling incentives from selection}

To empirically disentangle (H2.1) and (H2.2) as alternative explanations of the impact of the wage on performance, we need to introduce further notation and assumptions. Using

\footnotetext{
${ }^{7}$ See Hahn, Todd, and Van der Klaauw (2001) for a discussion of identification assumptions in RDD.
} 
an additive specification, as it is typical in a diff-in-diff strategy, we rewrite potential performance in the following form: $Y_{k}=S\left(X_{k}+v_{k}\right)+I_{k}$, where the function $S($.$) captures$ the impact of the potential observable characteristics $X_{k}$ and the unobservable characteristics $v_{k}$ on performance, and $I_{k}$ represents the incentive effect associated with the wage $W_{k}{ }^{8}$ For example, if $v_{h}>v_{\ell}$, citizens attracted to politics by $W_{h}$ have unobservable skills that improve their performance with respect to citizens attracted to politics by $W_{\ell}$. Based on this formulation, the effect of the wage on performance can be decomposed as $\tau_{\text {per }}=\sigma_{\text {per }}+\phi_{\text {per }}$, where:

$$
\begin{gathered}
\sigma_{p e r} \equiv E\left[S\left(X_{h}+v_{h}\right)-S\left(X_{\ell}+v_{\ell}\right) \mid P=P_{c}\right] \\
\phi_{\text {per }} \equiv E\left[I_{h}-I_{\ell} \mid P=P_{c}\right] .
\end{gathered}
$$

To identify these average treatment effects, we exploit an additional feature of the Italian institutional framework. Because of a term limit, mayors cannot spend more than two consecutive terms in office. We can thus introduce the following assumption.

Assumption 3 The incentive effect of the wage on performance is at work only when the term limit is not binding (reelection motive).

Note that this assumption does not mean that mayors in the second term have no incentives to perform well. They may still want to do their best because they plan to run for higher offices; because they want to be remembered for their positive legacy; or simply because of intrinsic motivations. The important point is that all of these incentives do not depend on the wage, as reelection in the same town no longer belongs to the mayor's opportunity set. Whenever the term limit is binding, incentives are therefore identical for mayors just below or just above $P_{c}$. Let $T L$ be an index for the term limit, with $T L=0$ when the term limit constraint is slack (that is, the mayor is in the first term), and $T L=1$ when it is binding (that is, the mayor is in the second term). Potential outcomes now depend not only on $W$, but also on $T L$, that is, $Y_{k j}$, with $j \in\{0,1\}$. Under Assumption 3 , they can be summarized as follows.

\footnotetext{
${ }^{8}$ One might think of alternative specifications of $Y$, e.g., including an interaction term between $\left(X_{k}+v_{k}\right)$ and $I_{k}$ to capture the different outside opportunities of mayors attracted by different wage levels. However, as it will become clear in the rest of this section, we partial out any heterogeneity in the individual outside option when we compute the difference of $Y$ over the terms for the same mayor.
} 


\begin{tabular}{ccc}
\hline \hline & $W=W_{\ell}$ & $W=W_{h}$ \\
\hline $\mathrm{TL}=0$ & $Y_{\ell 0}=S\left(X_{\ell 0}+v_{\ell 0}\right)+I_{\ell}$ & $Y_{h 0}=S\left(X_{h 0}+v_{h 0}\right)+I_{h}$ \\
$\mathrm{TL}=1$ & $Y_{\ell 1}=S\left(X_{\ell 1}+v_{\ell 1}\right)+\exp$ & $Y_{h 1}=S\left(X_{h 1}+v_{h 1}\right)+\exp$ \\
\hline \hline
\end{tabular}

Here, exp stands for administrative experience, which we assume to affect performance independently of the wage schedule. ${ }^{9}$ The above table shows that mayors in the first term and mayors in the second term might have different skills. In particular, as long as performance is relevant for reelection, we expect mayors at $T L=1$ to be more skilled according to both observable and unobservable characteristics. In general: $S\left(X_{k 0}+v_{k 0}\right) \neq$ $S\left(X_{k 1}+v_{k 1}\right)$. If we restrict the analysis to the sample of politicians who are elected for two consecutive terms, however, we have that: $S\left(X_{k 0}+v_{k 0}\right)=S\left(X_{k 1}+v_{k 1}\right)$.

In this context, we can identify the overall effect of the wage on performance as:

$$
\tau_{p e r}=E\left[Y_{h 0}-Y_{\ell 0} \mid P=P_{c}\right]=\lim _{P \downarrow P_{c} \mid T L=0} Y-\lim _{P \uparrow P_{c} \mid T L=0} Y
$$

where the first equality follows from Assumption 3 and the sample restriction to politicians elected for two consecutive terms, while the second equality follows from Assumption 2.

Similarly, we can identify the composition effect and the incentive effect of the wage on performance, respectively, as:

$$
\begin{gathered}
\sigma_{p e r}=E\left[Y_{h 1}-Y_{\ell 1} \mid P=P_{c}\right]=\lim _{P \downarrow P_{c} \mid T L=1} Y-\lim _{P \uparrow P_{c} \mid T L=1} Y, \\
\phi_{p e r}=E\left[\left(Y_{h 0}-Y_{h 1}\right)-\left(Y_{\ell 0}-Y_{\ell 1}\right) \mid P=P_{c}\right]= \\
=\left(\lim _{P \downarrow P_{c} \mid T L=0} Y-\lim _{P \uparrow P_{c} \mid T L=0} Y\right)-\left(\lim _{P \downarrow P_{c} \mid T L=1} Y-\lim _{P \uparrow P_{c} \mid T L=1} Y\right) .
\end{gathered}
$$

In both equations, the first equality follows from Assumption 3 and the sample restriction to reelected politicians, while the second equality follows from Assumption 2. ${ }^{10}$

\footnotetext{
${ }^{9}$ If experience enhanced performance more for high-skilled than for low-skilled mayors (that is, $\exp _{h}>$ $\left.\exp _{\ell}\right)$, we could still identify the overall effect of the wage on performance, but we would overestimate (underestimate) the composition (incentive) component. In Section 5.3, we come back to this point from an empirical point of view and show that the effect of administrative experience on performance does not depend on political selection.

${ }^{10}$ To leave the framework as simple as possible, so far we have not contemplated the pure motivational effect of an increase in the salary on performance (Akerlof, 1982). Experimental evidence suggests this effect being relatively small (Gneezy and List, 2006). If there were any, the potential performance should be rewritten as: $Y_{k}=S\left(X_{k}+v_{k}\right)+I_{k}+M_{k}$, where $M_{k}$ represents the morale effect associated with the wage $W_{k}$. It is easy to show that, while $\phi_{\text {per }}$ would still identify the incentive effect $\left(M_{k}\right.$ would cancel out in
} 


\subsection{Estimation}

In order to test (H1), (H2), (H2.1), and (H2.2), we need to implement equations (1), (3), (4), and (5). Basically, this is a problem of estimating the boundary points of two (or four) regression functions. Various semiparametric and nonparametric methods have been proposed for that purpose. We apply both a local linear regression approach as suggested by Imbens and Lemieux (2008) and a split polynomial approximation in the spirit of Lee (2008). The first method fits linear regression functions to the observations distributed within a distance $\Delta$ on either side of the threshold. To implement equation (1), we restrict the sample to towns in the interval $P_{i} \in\left[P_{c}-\Delta, P_{c}+\Delta\right]$ and estimate the model:

$$
X_{i}=\delta_{0}+\delta_{1} P_{i}^{*}+D_{i}\left(\gamma_{0}+\gamma_{1} P_{i}^{*}\right)+\eta_{i}
$$

where $X_{i}$ captures some observable traits of the mayor or candidates, $D_{i}$ is a treatment dummy equal to one if $P_{i} \geq P_{c}$, and the normalized variable $P_{i}^{*}=P_{i}-P_{c}$ allows us to interpret $\gamma_{0}$ as the jump between the two regression lines at $P_{c}$. As a result: $\tau_{s e l}=\gamma_{0}$. We select the bandwidth $\Delta$ in two ways: applying a cross-validation method (Ludwig and Miller, 2007); dividing the optimal bandwidth by half to assess the sensitivity of the results to the chosen $\Delta$ (Imbens and Lemieux, 2008). ${ }^{11}$ As the same city is observed in different terms, we control for intra-city correlation in the error term $\eta_{i}$.

As an alternative to local linear regression, we use the whole sample and choose a flexible functional form specification to fit the relationship between $X_{i}$ and $P_{i}$ on either side of $P_{c}$. Specifically, we estimate the model:

$$
X_{i}=\sum_{k=0}^{p}\left(\delta_{k} P_{i}^{* k}\right)+D_{i} \sum_{k=0}^{p}\left(\gamma_{k} P_{i}^{* k}\right)+\eta_{i} .
$$

Usually, a third-grade polynomial $(p=3)$ is used in the empirical literature. This method is attractive for many reasons, although a possible concern is that it may be sensitive to outcome values of observations far away from the threshold.

equation 5), the same would not be true for $\sigma_{\text {per }}$ in equation (4), as it would contain both the composition and the motivational effect. We might worry the latter component being particularly important in the political arena, where work norms are more effective as mayors' decisions are always under the spotlight. In this case, $\sigma_{\text {per }}$ should then be interpreted as a broader complement of the incentive effect.

${ }^{11}$ The cross-validation method consists in choosing $\Delta$ so as to minimize the loss function: $C V_{X}(\Delta)=$ $\frac{1}{N} \sum_{i=1}^{N}\left(X_{i}-\hat{X}_{\Delta}\left(P_{i}\right)\right)^{2}$, where, for every $P_{i}$ to the left (right) of the threshold $P_{c}$, we predict $\hat{X}_{\Delta}\left(P_{i}\right)$ as if it were at the boundary of the estimation using only observations in the interval $\left[P_{i}-\Delta, P_{i}\right]\left(\left[P_{i}, P_{i}+\Delta\right]\right)$. We choose the optimal $\Delta$ among all multiples of 50 up to 1,500 . 
In a similar way, to implement equations (3), (4), and (5), we fit two different regression functions on both sides of the threshold $P_{c}$ : one for politicians without a binding term limit $(T L=0)$ and one for politicians with a binding term limit $(T L=1)$. The jump in the regression functions for the subsample $T L=0$ can be interpreted as an estimate of $\tau_{p e r}$, while the jump in the regression functions for the subsample $T L=1$ can be seen as an estimate of $\sigma_{p e r}$. The difference between the two jumps produces an estimate of $\phi_{p e r}$. Formally, with the local linear regression approach, we choose $\Delta$ with cross-validation, restrict the sample to cities in the interval $P_{i} \in\left[P_{c}-\Delta, P_{c}+\Delta\right]$, and estimate the model:

$$
Y_{i}=\delta_{0}+\delta_{1} P_{i}^{*}+D_{i}\left(\gamma_{0}+\gamma_{1} P_{i}^{*}\right)+\left(1-T L_{i}\right)\left[\alpha_{0}+\alpha_{1} P_{i}^{*}+D_{i}\left(\beta_{0}+\beta_{1} P_{i}^{*}\right)\right]+\xi_{i},
$$

where $Y_{i}$ is some performance indicator for the mayor, $D_{i}$ the treatment, and $P_{i}^{*}$ the normalized population size. Standard errors are clustered at the city level. It is straightforward to show that the overall effect of the wage on performance is $\tau_{p e r}=\gamma_{0}+\beta_{0}$ (when $\left.T L_{i}=0\right)$, while the composition effect on performance is $\sigma_{p e r}=\gamma_{0}\left(\right.$ when $\left.T L_{i}=1\right)$. It follows that the incentive effect on performance is $\phi_{p e r}=\tau_{p e r}-\sigma_{p e r}=\beta_{0}$. Analogously, with the split polynomial approximation, we estimate the model:

$$
Y_{i}=\sum_{k=0}^{p}\left(\delta_{k} P_{i}^{* k}\right)+D_{i} \sum_{k=0}^{p}\left(\gamma_{k} P_{i}^{* k}\right)+\left(1-T L_{i}\right)\left[\sum_{k=0}^{p}\left(\alpha_{k} P_{i}^{* k}\right)+D_{i} \sum_{k=0}^{p}\left(\beta_{k} P_{i}^{* k}\right)\right]+\xi_{i}
$$

where the overall, composition, and incentive effects of the wage on performance are identified as above: $\tau_{p e r}=\gamma_{0}+\beta_{0} ; \sigma_{p e r}=\gamma_{0} ; \phi_{\text {per }}=\beta_{0}$.

\section{Data}

\subsection{Institutional framework}

The Italian municipal government (Comune) is composed by a mayor (Sindaco), an executive committee (Giunta) appointed by the mayor, and an elected council (Consiglio Comunale) that supervises the legislative activity of the mayor and endorses the proposed policies (including the annual budget) with majority rule. Since March 1993, mayors are directly elected by citizens with plurality rule (single round below 15,000 inhabitants and runoff above) and are subject to a two-term limit (unless, after April 2000, one of the two terms lasted for less than two years). In 1993, the duration of a legislative term was 
reduced from five to four years, then restored to five years in 2000. Italian municipalities are in charge of a vast number of services, from water supply to waste management, from municipal police to certain infrastructures, from housing to welfare policies.

The remuneration of the mayor depends on the size of the resident population, as measured by the national Census that takes place every ten years, and sharply changes at nine different thresholds. ${ }^{12}$ Nominal salaries have been adjusted almost every year to account for price inflation, so that real values within each population bracket have remained almost unchanged from 1993 to 2004 (see Table 1), in line with the trend in national per capita income. ${ }^{13}$ Since adjustments were applied uniformly to all municipalities, the relative wage between different population brackets also remained identical across time. ${ }^{14}$

The mayor's wage, however, is not the only policy varying with population size. In Table 2, we present a summary of all the policies based on population brackets. Besides the salary of the mayor, population size also determines the compensation of the members of the executive committee (between 15 and 75 percent of the mayor's) and of the councillors (as of 2000, a fiche between 18 and 36 euros for each session attended); the size of the council (ranging from 12 to 60); the size of the executive committee (ranging from 4 to 16); the electoral rule (single round versus runoff voting); whether or not a municipality can have additional elective bodies in every neighborhood.

Table 2 shows that only three out of the nine wage thresholds determine a variation solely in the remuneration of the mayor (or of the other members of the municipal government): 1,000, 5,000, and 50,000. In all of the other cases, in fact, the wage increase overlaps with additional policies whose effect cannot be dismissed. Because the wage increase at 1,000 was only introduced in April 2000 and our dataset does not contain budget information after 2005, we cannot use this threshold in our analysis, as we are unable to calculate performance indicators for mayors elected for two consecutive terms after 2000. Because of the very small sample size around 50,000 inhabitants (see Table 3), we cannot

\footnotetext{
${ }^{12}$ For the period covered in our sample, two Censuses were held in 1991 and 2001.

${ }^{13}$ The average real disposable income remained almost unchanged from the beginning to the end of the 1990s in Italy, decreasing in the first half and going back to the initial level in the second half. Source: Bank of Italy, Survey of Household Income and Wealth (SHIW), waves 1993-2004. Employed individuals between 18 and 65; gross income (as employee, self-employed, or entrepreneur) recovered by increasing the disposable income available in the SHIW by the corresponding tax rate.

${ }^{14}$ Legislative references in hierarchical and chronological order: Laws 816/1985, 81/1993, and 265/1999; Decreti del Ministero dell'Interno 11/4/1988, 2/4/1991, 4/7/1994, 12/3/1997, and 4/4/2000.
} 
use this threshold either. As a result, we focus on the 5,000 threshold only, with an additional caveat: since 2002, municipalities above 5,000 are subject to the Internal Stability Pact, a set of rules decided by the national government to improve fiscal discipline at the municipality level. We therefore restrict our analysis to mayoral terms from 1993 to 2001.

As of 2000, the real gross wage of the mayor ranges from 1,291 euros per month for municipalities with less than 1,000 inhabitants up to 7,798 euros for those with more than 1,000,000 people (see Table 2). At the 5,000 threshold, the gross salary of the mayor increases by $28.6 \%$ (from 2,169 to 2,789 euros), which is $33.3 \%$ before 2000 (see Table 1 ). These numbers are quite sizable if compared to the rest of the population. In 2000, the average gross labor income in Italian cities with less than 5,000 inhabitants was 1,375 euros per month for men and 1,067 for women, while in cities between 5,000 and 20,000 it was 1,468 and 1,135, respectively. ${ }^{15}$ Especially in small cities, it seems that being appointed as mayor provides a significant source of income for a large fraction of the population.

Before moving to the data, it is worth addressing three specific aspects of the Italian institutional framework that, to a certain extent, might affect the interpretation of our results. First of all, the compensation of the members of the executive committee changes along with the compensation of the mayor. Although the overall effect might be interesting per se (that is, the effect of an increase in the salary of all the members of the executive office), we cannot separately identify the effect of a change in the wage of the mayor. However, since the magnitude of the compensation of the executive committee is very small, it is plausible to assume that the main effect of increasing the remuneration of elected officials is actually driven by the mayor being paid more, the compensation packages for other politicians being second-order.

Second, mayors can keep their job and cumulate earnings, the only restriction being that if they work as dependent employees, they have to ask for a leave-of-absence, otherwise the salary is cut by half. ${ }^{16}$ The possibility of making outside income, however, only affects the external validity of our results. In other words, what we are estimating is the impact of politicians' wage in a situation where the elective office is compatible with outside work, as opposed to the situation in which it is not, and we know from the discussion in Section

\footnotetext{
${ }^{15}$ Source: see footnote 13.

${ }^{16}$ Strict incompatibilities apply instead to any appointment in companies or entities under the control of the municipality (see Decreto Legislativo 267/2000).
} 
2.1 that the impact of the wage on political selection may differ in the two cases (see Gagliarducci, Nannicini, and Naticchioni, 2008). To assess the relevance of outside work in our data, we conducted a phone interview survey of all mayors in towns from 4,900 to 5,100 inhabitants (in office on May 1, 2009). We obtained replies from 36 out of 57 mayors. The fraction of part-time mayors was $53 \%$, with the others working full-time as mayor. Importantly, this fraction was almost identical for towns below and above 5,000 (54\% and $53 \%$, respectively). ${ }^{17}$ It seems therefore that the time devoted to office is relevant and potentially associated to a sizable opportunity cost. Furthermore, it should be noted that outside income is an important motivation also for politicians at the national level, given that it is unconstrained in almost all parliaments of democratic countries, the only exception being the U.S. Congress.

Finally, under specific and documented circumstances, the executive committee can grant up to an additional 15\% increase to the mayor, conditional on the approval of the Ministry of Internal Affairs. If applied, this policy would simply change the (quantitative) interpretation of the estimated effects. Suppose for example that all towns above 5,000 chose to increase the salary, while all towns below did not. In this case, we would estimate the effect of a $48 \%$ wage increase. In the opposite case, where all towns above 5,000 increase the salary, while the others do not, there is a $18 \%$ increase. According to the mentioned survey of mayors around 5,000, however, only very few municipalities (two out of 36 , both above the threshold) introduced a wage raise, so that we can confidently conclude that we are estimating the impact of a $33 \%$ wage increase at 5,000.

\subsection{Sample selection and variables}

The original dataset contains the mayoral terms elected from 1993 to 2005 for all Italian municipalities. It carries information about gender, age, highest educational attainment (self-declared), political affiliation, and previous job (self-declared) of the elected mayor and the losing mayoral candidates, as well as yearly information at the municipality level about the budget components (i.e., subcategories of revenues and expenditures) and some administrative indicators (i.e., speed of revenues collection and payment). ${ }^{18}$

\footnotetext{
${ }^{17}$ The (self-declared) weekly working hours of full-time mayors were 38, those of part-time mayors 28.

${ }^{18}$ The individual-level data were provided by the Statistical Office of the Italian Ministry of Internal Affairs, the town-level data by ANCI (Associazione Nazionale Comuni Italiani).
} 
Table 3 shows that the Italian territory is very fragmented, with the great majority of the municipalities having a population size below 10,000 (about $87.0 \%$ as of 1991, and $86.6 \%$ as of 2001$)$, or even below 5,000 ( $72.7 \%$ as of 1991 , and $72.2 \%$ as of 2001$)$. It is also worth noticing that no much changed in the population distribution between the 1991 Census and the 2001 Census, which is reassuring against the presence of migration flows in reaction to policy changes at different population thresholds. ${ }^{19}$

In Table 4, we pool together all the mayoral terms between 1993 and 2001 and summarize the characteristics of both the three best candidates and the elected mayor for whom we have non-missing information - 31,822 candidates and 16,393 mayors - by population size. $^{20}$ On average, $7 \%$ of the candidates are women, aged 46.6 , and with about 13.8 years of schooling (i.e., high-school level). Almost 14\% were not employed (either unemployed or out of the labor force) before the election, while $45 \%$ were employed in high-skilled occupations (lawyers, professors, physicians, self-employed, and entrepreneurs), and 20\% in low-skilled occupations (blue collars, clerks, and technicians), with other types of jobs in the residual category. As far as the population size increases, candidates are more educated, less likely to be non-employed or low-skilled, and more likely to be high-skilled. These patterns are likely to pass-through to the winner of the electoral race. Accordingly, we also observe similar levels and trends for the elected mayors.

As budget indicators we use the following variables per capita (and per calendar year): total expenditure, total revenues, and deficit. To assess budget management and priorities, we also look at the following items: i) expenditure for investments ("capital expenditure"), personnel and debt service ("rigid expenditure"), or goods and services ("current expenditure"); ii) revenues from transfers (from the European Union, the national, or the regional government), taxes, or tariffs. All variables are averaged over the term, excluding election years to avoid the overlapping of different mayors over the same calendar year. ${ }^{21}$ Because of missing observations, the budget sample is smaller: 14,115 mayoral terms.

\footnotetext{
${ }^{19}$ Between 1991 and 2001, only 40 cities moved from above to below 5,000 and 105 from below to above. Differences in population growth above and belove the policy thresholds are never statistically significant.

${ }^{20}$ We could not recover information about any other candidate. However, only $2.79 \%$ of the electoral races had more than three candidates, $18.92 \%$ had exactly three, $63.37 \%$ had two, and $14.92 \%$ were uncontested.

${ }^{21}$ Municipal elections in Italy are usually held in the late Spring, so that the electoral and the calendar year do not coincide. All the results on budget performance are also robust to the exclusion of the last full calendar year in office, which might capture a lame-duck effect.
} 
To further evaluate the efficiency of the municipal government, we look at two additional performance measures: the speed of revenues collection (that is, the ratio between the collected tax and transfer revenues and the total amount of assessed revenues that the municipality should collect) and the speed of payment (that is, the ratio between the outlays actually paid and the outlays committed in the municipality budget). These measures are particularly suited for inferring about the administrative IQ of mayors, while this is not necessarily the case with the other budget variables, which might also reflect policy preferences.

Table 5 contains descriptive statistics of the performance indicators (in 2000 real terms for per capita variables). On average, total expenditure amounts to 1,401.93 euros per capita, total revenues to 1,382.20 euros, and the resulting average deficit is 19.73 euros. Both revenues and expenditure have a U-shaped relationship with population size: they decrease at first, possibly because of economies of scale in running the administrative machine, and then rise again for cities above 50,000, where more infrastructures are usually undertaken. When we look at the composition of revenues and expenditure, we can see that $41 \%$ of the expenditure is used to cover investments or other capital outlays (570.01), $29 \%$ to cover personnel costs and the debt service (404.30 euros), and the remaining 30\% to purchase goods and services (428.28). As for revenues, $70 \%$ are made of transfers (961.07 euros), while $19 \%$ are local taxes (264.98), and $11 \%$ are tariffs for municipal services (156.15). On average, only $65.5 \%$ of due taxes are actually collected over the year, while $79.5 \%$ of due payments are actually disbursed over the year.

For the reasons discussed in the previous section, we restrict the sample to the 5,000 threshold, and, for estimation purposes, to cities between 3,250 and 6,750 resident inhabitants, so as to stay sufficiently away from other thresholds. This leaves us with 3,039 mayoral terms around 5,000. In most estimations reported in the next section, the sample size is further restricted according to the bandwidth choice $(\Delta)$ and the sample restriction to mayors reelected for two consecutive terms (see Section 3). 


\section{Empirical results}

\subsection{Testing for nonrandom sorting above the threshold}

In this section, we assess the validity of the RDD identification strategy discussed in Section 3 with two different testing procedures. First, to formally check for the absence of manipulation of the running variable at 5,000 (violated if mayors were able to alter population size and sort above the threshold), we test the null hypothesis of continuity of the density of population size at 5,000 as proposed by McCrary (2008). Second, we check whether invariant characteristics of the municipalities, such as area size and geographic location, are balanced in the neighborhood of 5,000.

In Figure 1, we plot the frequency of municipalities with less than 20,000 inhabitants, using different binsizes (100, 250, and 500 inhabitants) for the 2001 Census. ${ }^{22}$ We can see that the distribution is positively skewed, with a pick around 700. Visual inspection does not reveal any clear discontinuity at the wage thresholds (1,000 and 5,000), although the same is not true for the other policy thresholds $(3,000,10,000$, and 15,000), where it seems that cities managed to sort just above the policy cutoff. Although the Census is run independently by the National Statistical Office, so that false reporting should be ruled out, it could still be the case that municipalities succeed in sorting above the thresholds by attracting citizens to their territory from other towns (e.g., by means of urbanization plans or tax rebates for owners who acquire their official residence in the municipality). For this reason, in Figure 2, we zoom on the shape of the running variable around the 5,000 threshold. There, no evidence of manipulative sorting can be detected.

We formally test for the presence of a density discontinuity at the 5,000 threshold in Figure 3, where a McCrary test is performed by running kernel local linear regressions of the log of the density separately on both sides of the threshold (McCrary, 2008). As we can see from the figure, the log-difference between the frequency to the right and to the left of the threshold is not statistically significant. In fact, the point estimate is -0.007 (with a standard error of 0.236). ${ }^{23}$ We are aware that a density test may have

\footnotetext{
${ }^{22}$ We do not consider municipalities above 20,000 inhabitants because of the small sample size in that range. Figures for the 1991 Census are identical and are available upon request (see also Table 3).

${ }^{23}$ The computed optimal bandwidth is 546.33, while the computed optimal binsize is 52.16 . We thank Justin McCrary for providing us with the Stata codes to perform this test.
} 
low power if manipulation has occurred on both sides of the threshold. In that case, the monotonicity assumption does not hold, and there might be nonrandom sorting even if this would not be detected in the distribution of the running variable. However, we do not know of any reason why mayors may want to sort below 5,000, while the wage policy provides an incentive to sort above the threshold. The evidence of no sorting above 5,000 is thus reassuring. Mayors alone are not able (or willing) to manipulate population size: in fact, even if they did it, they would not stay in power enough time (especially after the introduction of the two-term limit) to grasp the benefits of sorting above the 5,000 threshold in the following Census. On the contrary, we may expect a broader interest for twisting the population size at other thresholds, where all the local politicians have the incentive to coordinate their efforts to attract new residents, so as to increase political offices and rents.

In Table 6, we further check for manipulative sorting by performing balance tests on the available invariant town characteristics. If there were nonrandom sorting, we should expect some of these characteristics to differ systematically between treated and untreated municipalities around 5,000. The available pre-treatment characteristics are the size of the geographical area and the location, because all the other variables in the dataset are endogenous to the policy. The balance tests are performed using a procedure similar to the McCrary test, with separate weighted kernel estimations on both sides of the discontinuity point. ${ }^{24}$ No pre-treatment characteristics show a significant discontinuity at the 5,000 threshold. In particular, the geographical location, which in Italy might be correlated with social capital and administrative culture, is perfectly balanced. ${ }^{25}$ Interestingly, even the political party affiliation of the mayor is well balanced around the threshold. Although this is not a pre-determined characteristic, it is reassuring to find that it is balanced as well, because it guarantees that the differences we may find in budget performance are not due to different political views on the way fiscal policy should be conducted.

\footnotetext{
${ }^{24}$ We use a binsize equal to 10 and three different bandwidths: 125,150 , and 175 .

${ }^{25}$ Indeed, Nannicini (2009) finds that manipulative sorting at 3,000, 10,000, 15,000, and 30,000 only takes place in areas with low social capital, as measured by blood donation and non-profit organizations. Also in those areas, however, there is no manipulation at the 1,000 and 5,000 wage thresholds.
} 


\subsection{The effect of the wage on political selection}

In this section, we analyze whether paying politicians more affects the selection into politics. In Table 7 and Table 8, we look at whether a higher remuneration has an effect on the quality of the best three candidates and the elected mayors, respectively, by estimating equation (6) with local linear regression and equation (7) with a split polynomial.

As we can see in Table 7, the 33\% wage increase (28\% after 2000) at the 5,000 threshold has a sizable and statistically significant impact on the educational level of candidates. Candidates to a better paid office turn out to have from 0.905 to 1.205 years of schooling more. This corresponds to an increase from $+6.4 \%$ to $+8.6 \%$ with respect to the average value of 14.06 years in the 3,000-5,000 population bracket. Using the half optimal bandwidth and the third-grade split polynomial approximation, we also detect a positive effect on the proportion of high-skilled candidates (9.2 and 16.2 percentage points more, respectively, $+18 \%$ and $+33 \%$ with respect to an average of 0.49 ). This selection effect of the wage on the quality of candidates transfers almost one-to-one into the quality of elected mayors. The impact on the mayors' education ranges from $0.879(+6.2 \%)$ to 1.633 $(+11.5 \%)$ years of schooling more. And the impact on the fraction of high-skilled mayors is positive with the half bandwidth and the split polynomial. ${ }^{26}$

These results are consistent with the descriptive plots in Figure 4 and Figure 5, where we draw scatters of the observed values, plus a running-mean smoothing performed separately on either side of the threshold. The sharp jump when moving from the left to the right of the threshold is particularly evident for the years of schooling, but not for the other variables, where there is more noise.

In Table 9, we perform a robustness check including the available predetermined variables (that is, geographical size and location) as covariates in the baseline local linear regression specification. If these variables were balanced around the threshold, estimates should be insensitive to their inclusion. We do not detect any difference with respect to the baseline estimates. In Table 10, we implement placebo tests by estimating the treatment effect at fake thresholds, where there should be no effect. In particular, we look at the median below and the median above 5,000 inhabitants, excluding cities within 250 inhabitants from other true policy cutoffs. We then estimate the treatment effect on

\footnotetext{
${ }^{26}$ Results are robust to the use of a fourth-grade polynomial (available upon request).
} 
several variables using the split polynomial. With only one exception, the effects at the fake thresholds are never statistically different from zero. ${ }^{27}$

To sum up, the $33 \%$ wage increase at 5,000 is able to attract more educated candidates. Not surprisingly, this translates into more educated mayors. The effect of the wage on education at the 5,000 threshold is always statistically significant, most of the time at the $1 \%$ level. Indeed, if we take into account that, in municipalities below 5,000 inhabitants, the gross labor income per month for people without (with) a high-school degree was on average $1,137(1,357)$ euros in 2000 , while people with college education earned 1,594 euros, the selection effect of a wage increase of 620 euros is hardly surprising. ${ }^{28}$ There is also some evidence that a higher wage attracts relatively more politicians employed in high-skilled occupations, pointing to the fact that the time devoted to the office is an important component of the opportunity cost of entering politics (the gross labor income per month for high-skilled people was on average 1,352 euros in 2000). ${ }^{29}$

\subsection{The effect of the wage on performance}

We now investigate whether the salary affects the way the mayor runs the municipality. Specifically, we estimate equation (8) with local linear regression and equation (9) with a split polynomial, to obtain both the overall effect of the wage on performance (identified on mayors with a slack term limit) and the composition effect of the wage on performance (identified on mayors with a binding term limit), recovering at the same time the incentive effect as the difference between the two.

\footnotetext{
${ }^{27}$ Placebo tests at the $25^{\text {th }}$ and $75^{t h}$ percentiles deliver the same conclusion, but the sample size is considerably lower (results available upon request).

${ }^{28}$ Source: see footnote 13 . We also performed the RDD estimations separately for the North and the South of the country. The effect of the wage on years of schooling and high-skilled occupations remains statistically different from zero in both samples, but the point estimates are greater in the South, where the lower cost of living amplifies the impact of a wage increase (results available upon request).

${ }^{29}$ We ran the same exercise for the available data around the 1,000 threshold (from 2000 only), and found that a $12 \%$ wage increase (see Table 1) is not enough to motivate highly educated citizens to enter politics (results available on a previous working-paper version of this paper, see Gagliarducci and Nannicini, 2008). At 1,000 inhabitants, we only observe a pale reduction in the percentage of candidates employed in low-skilled occupations. While we would be tempted to attribute the different effect between the 1,000 and 5,000 threshold to the intensity of the treatment, we have to acknowledge that the two (local) results refer to different time periods (2000-2007 and 1993-2001, respectively), and that the composition of the reference labor force might also differ greatly in the two situations (e.g., less high-skilled and college graduates in smaller cities). Furthermore, the wage might have a delayed effect on political selection, not captured in the exercise at 1,000 because this threshold was only introduced in 2000 .
} 
If we look at the overall effect, the first result to notice in Table 11 is that paying a mayor $33 \%$ more reduces the size of the municipality budget, as both total expenditure and revenues per capita decrease by a significant amount (-199.59 and -196.21 euros, respectively, in both cases about $-17.6 \%$ with respect to the 3,000-5,000 average values). Looking at expenditure subcategories, we can see that the budget reduction is mostly driven by a significant cut in expenditure for goods and services (-86.46 euros, $-21.8 \%)$. Personnel expenditure is reduced by 35.75 euros $(-11.1 \%)$, while for investments the reduction is not statistically significant. As for collected revenues, there is a consistent reduction in taxes and, especially, tariffs (-31.81 and -121.85 euros, respectively, $-12.6 \%$ and $-75 \%$ ), while there is no significant evidence of a decline in transfers from the other levels of government. We find very similar results using the half bandwidth or the split polynomial approximation, although the reduction in taxes loses statistical significance. Since revenues and expenditure move in the same direction, the effect on the deficit is not statistically different from zero. A graphical representation of the overall effect of the wage on the budget variables can be found in Figure 6 .

Looking at the other estimates in Table 11, it is clear, though, that most of the overall effect comes from the selection of different politicians, rather than from the interaction between a high wage and the willingness to be reelected. ${ }^{30}$ As a matter of fact, the incentive effect is never significant, both in size and in statistical terms. Among mayors with a binding term limit (composition effect), instead, those who are paid more reduce expenditures, taxes, and tariffs. In other words, for the reduction in taxes, tariffs, and current expenditure, selection is clearly the driving force behind the overall effect. ${ }^{31}$

\footnotetext{
${ }^{30}$ Note that $66 \%$ of mayors rerun for a second term, and $78 \%$ of them are reelected. As a matter of fact, we also find that being paid more has an effect on the decision to run for reelection ( 8 percentage points more, significant at the $5 \%$ level), but not on the probability of being reelected or on the margin of victory. This is because, as we showed in the previous section, a higher wage also attracts a better pool of (losing) candidates.

${ }^{31}$ As discussed in Section 3.2, mayors in the second term might also have the incentive to perform well because they plan to run for higher offices. As these incentives do not depend on the wage, they should not affect our identification strategy, unless they were completely first-order. We actually observe that, in municipalities between 3,500 and 6,500 inhabitants, only $5.3 \%$ of the mayors were appointed in the provincial government after the term limit, $1.8 \%$ in the regional government, and $0.4 \%$ in the national parliament. Importantly, we do not detect any difference in the career prospects of mayors above and below the 5,000 threshold.
} 
This exercise, of course, is based on the assumption - shared by the literature on political agency and political budget cycles - that voters care about public revenues and expenditures, and keep politicians accountable for the government budget. An alternative explanation for the lack of a reelection incentive could be that Italian voters have strong ideological preferences ("party alignment"), which makes the threat of non-reelection less credible. To be sure that this is not the case, in the top panel of Table 12, we run the same exercise as in Table 11 restricting the sample to mayors whose electoral margin in the first term was small, that is, mayors who obtained less than $55 \%$ of the votes. In this subsample, one can expect swing voters to be decisive and then the reelection motive to be stronger. Even in this case, there is no evidence that a higher wage has an impact through the willingness to be reelected, which makes us think that our result simply reflects the strength of the composition effect over the incentive effect of the wage.

A second robustness check concerns administrative experience. In the framework outlined in Section 3.2, we assumed that all mayors without a binding term limit were in the first term, while all mayors with a binding term limit were in the second term. However, this is not always the case in the data. When the term limit was introduced, in fact, it only applied to terms elected after 1993, no matter the previous ones. For this reason, we observe some mayors in the third or fourth term. In the middle panel of Table 12, we present the same estimates as in Table 11 but restricting the sample to mayors elected for the first time after March 1993. The results are almost unchanged. We conclude that differences in administrative experience do not bias our baseline results. This is also reassuring about our assumption that the effect of experience is the same above and below 5,000 inhabitants (see again Section 3.2), otherwise this robustness exercise should differ from the baseline results.

In the bottom panel of Table 12, we perform the same robustness check as for the estimates on political selection; that is, we include the invariant town characteristics as additional covariates in the local linear regression estimation. As we can see, the results are almost identical in terms of magnitude to the ones presented in the top panel of Table 11. Finally, in Table 13, we test for the treatment effect at fake thresholds, where there should be no effect. No jump is ever statistically different from zero. 
Although we cannot observe the quality of public goods and services provided at the municipality level, the above evidence on the reduction of the government size is consistent with the fact that the $33 \%$ wage increase at 5,000 attracts skilled citizens, who then run the government body more cautiously. In particular, they lower the tax and tariff burden, by reducing sources of waste in current outlays, while leaving almost unchanged other sources of expenditure. Indeed, empirical evidence about Italy shows that passive waste - that is, inefficiency due to red tape - is concentrated on expenditures for goods and services at the local level (Bandiera, Prat, and Valletti, 2009). An alternative interpretation of our results, however, is that the reduction in government size reflects differences in preferences; that is, a higher wage attracts more educated individuals, who are generally more reluctant toward redistribution even after controlling for income (Alesina and Giuliano, 2009). This would be true, on average, for candidates of both the center-left and center-right coalition (see Table 6). And voters could accept the implicit policy change in exchange for the greater competence of these politicians.

To shed more light on these two alternative exlanations, in Table 14, we perform the RDD estimations on the speed of revenues collection and the speed of payment, which we take as a better proxy for administrative efficiency. Although the effect is significant only at the $10 \%$ level, there is some evidence that better paid mayors increase the speed of revenues collection. According to the local linear regression estimation, they speed it up by about 4.5 percentage points (+6.9\% with respect to the 3,000-5,000 average value), while there is no robust evidence of an effect on the speed of payment. ${ }^{32}$ This is consistent with the view that, while the reduction in the government size could still reflect some differences in the preferences of the elected mayors, at least part of this effect is driven by a general improvement in the efficiency of the bureaucratic organization.

In Table 15, we run the same robustness exercises as for the budget variables, and find similar numbers, although the lower sample size for the two efficiency measures comes at the price of a reduction in statistical significance. Finally, placebo tests in Table 16 further reassure against the presence of any effect beyond the policy threshold.

\footnotetext{
${ }^{32}$ Note that this result is not in contrast with the reduction in tax revenues, as the speed of revenues collection follows a cash basis accounting, while tax revenues follow an accruals principle of accounting.
} 


\section{Conclusions}

In this paper, we have shown that paying politicians more has a positive effect on the quality of elected officials (that is, education and professional background), and it also affects the way they manage public finance. In particular, better paid politicians lower the size of the municipal government, by reducing taxes, tariffs, and current expenditure, as the result of an improvement in the efficiency of the municipal organization. Results also show that this performance effect is due to the selection of more skilled mayors, rather than the incentive to be reelected.

It is important to stress that our empirical exercise - which is local in nature as any RDD - cannot help determining the optimal wage level, that is, it cannot identify the upper limit over which the welfare benefit from paying politicians more is completely offset by the wage increase itself. Yet, it makes clear that the monetary remuneration is a relevant motivation for citizens willing to run for elective offices. While the obvious recommendation would be to increase the salary paid to politicians, our exercise also suggests that, in addition to population size, the salary could be linked to the private sector compensation for similar occupations. By doing so, voters could effectively compete with the market in recruiting competent citizens. 


\section{References}

Akerlof, G., 1982. Labor Contracts as Partial Gift Exchange. Quarterly Journal of Economics $97,543-569$.

Akerlof, G., Yellen, J.L. (eds.), 1986. Efficiency Wage Models of the Labor Market. Cambridge University Press.

Akhmedov, A., Zhuravskaya, E.V., 2004. Opportunistic Political Cycles: Test in a Young Democracy Setting. Quarterly Journal of Economics 119, 1301-1338.

Alesina, A., Giuliano, P., 2009. Preferences for Redistribution. NBER Working Paper 14825.

Bandiera, O., Prat, A., Valletti, T., 2009. Active and Passive Waste in Government Spending: Evidence from a Policy Experiment. American Economic Review, forthcoming.

Besley, T., 2004. Paying Politicians: Theory and Evidence. Journal of the European Economic Association 2, 193-215.

Besley, T., 2005. Political Selection. Journal of Economic Perspectives 19, 43-60.

Besley, T., Case, A., 1995. Does Electoral Accountability Affect Economic Policy Choices? Evidence from Gubernatorial Term Limits. Quarterly Journal of Economics 110, 769 798.

Besley, T., McLaren, J., 1993. Taxes and Bribes: The Role of Wage Incentives. Economic Journal 103, 119-141.

Bordignon, M., Tabellini, G., 2008. Moderating Political Extremism: Single vs Dual Ballot Elections. Mimeo, Bocconi University.

Brender, A., Drazen, A., 2008. How Do Budget Deficits and Economic Growth Affect Reelection Prospects? Evidence from a Large Panel of Countries. American Economic Review 98, 2203-20.

Brennan, G., Buchanan, J.M., 1980. The Power to Tax: Analytical Foundations of a Fiscal Constitution. Cambridge University Press.

Brollo, F., Nannicini, T., Perotti, R., Tabellini, G., 2009. Federal Transfers, Corruption, and Political Selection: Evidence from Brazil. Mimeo, Bocconi University.

Caselli, F., Morelli, M., 2004. Bad Politicians. Journal of Public Economics 88, 759-782. 
Chamon, M., de Mello, J.M.P., Firpo, S., 2008. Electoral Rules, Political Competition and Fiscal Spending: Regression Discontinuity Evidence from Brazilian Municipalities. PUC-Rio Discussion Paper 559.

Diermeier, D., Keane, M., Merlo, A., 2005. A Political Economy Model of Congressional Careers. American Economic Review 95, 347-373.

Di Tella, R., Fisman, R., 2004. Are Politicians Really Paid Like Bureaucrats? Journal of Law and Economics 47, 477-514.

Ferraz, C., Finan, C., 2007. Electoral Accountability and Corruption in Local Governments: Evidence from Audit Reports. IZA Discussion Paper 2843.

Ferraz, C., Finan, C., 2009. Motivating Politicians: The Impacts of Monetary Incentives on Quality and Performance. NBER Working Paper 14906.

Gagliarducci, S., Nannicini, T., 2008. Do Better Paid Politicians Perform Better? Disentangling Incentives from Selection. IGIER Working Paper 346.

Gagliarducci, S., Nannicini, T., Naticchioni, P., 2008. Outside Income and Moral Hazard: The Elusive Quest for Good Politicians. IZA Discussion Paper 3295.

Gneezy, U., List, J., 2006. Putting Behavioral Economics to Work: Field Evidence on Gift Exchange. Econometrica 74, 1365-1384.

Hahn, J., Todd, P., Van der Klaauw, W., 2001. Identification and Estimation of Treatment Effects with Regression Discontinuity Design. Econometrica 69, 201-209.

Imbens, G., Lemieux, T., 2008. Regression Discontinuity Designs: A Guide to Practice. Journal of Econometrics 142, 615-635.

Keane, M., Merlo, A., 2007. Money, Political Ambition, and the Career Decisions of Politicians. PIER Working Paper 07-016.

Lee, D.S., 2008. Randomized Experiments from Non-random Selection in the U.S. House Elections. Journal of Econometrics 142, 675-697.

List, J.A., Sturm, D.M., 2006. How Elections Matter: Theory and Evidence form Environmental Policy. Quarterly Journal of Economics 121, 1249-1281.

Ludwig, J., Miller, D., 2007. Does Head Start Improve Children's Life Chances? Evidence from a Regression Discontinuity Design. Quarterly Journal of Economics 122, 159208. 
Maskin, E., Tirole, J., 2004. The Politician and the Judge: Accountability in Government. American Economic Review 94, 1034-1054.

Mattozzi, A., Merlo, A., 2008. Political Careers or Career Politicians. Journal of Public Economics 92, 597-608.

McCrary, J., 2008. Manipulation of the Running Variable in the Regression Discontinuity Design: A Density Test. Journal of Econometrics 142, 698-714.

Messner, M., Polborn, M., 2004. Paying Politicians. Journal of Public Economics 88, 2423-2445.

Nannicini, T., 2009. Manipulative Sorting at Policy Discontinuities. Mimeo, Bocconi University.

Persson, T., Tabellini, G., 2000. Political Economics. MIT Press.

Pettersson-Lidbom, P., 2008. Does the Size of the Legislature Affect the Size of Government: Evidence from Two Natural Experiments. Mimeo, Stockholm University.

Pettersson-Lidbom, P., Tyrefors, B., 2009. The Policy Consequences of Direct versus Representative Democracy: A Regression Discontinuity Approach. Mimeo, Stockholm University.

Rogoff, K., 1990. Equilibrium Political Budget Cycles. American Economic Review 80, $21-36$.

Shapiro, C., Stiglitz, J., 1984. Equilibrium Unemployment as a Worker Discipline Device. American Economic Review 74, 433-444.

Smart, M., Sturm, D.M., 2006. Term Limits and Electoral Accountability. CEPR Discussion Paper 4272.

Van Rijckeghem, C., Weder, B., 2001. Bureaucratic Corruption and the Rate of Temptation: Do Wages in the Civil Service Affect Corruption, and By How Much? Journal of Development Economics 65, 307-331.

Weiss, A., 1980. Job Queues and Layoffs in Labor Markets with Flexible Wages. Journal of Political Economy 88, 526-538.

Yellen, J.L., 1984. Efficiency Wage Models of Unemployment. American Economic Review Papers and Proceedings 74, 200-205. 


\section{Tables and Figures}

Table 1: Mayor's gross monthly wage over time (in 2000 euros)

\begin{tabular}{|c|c|c|c|c|c|c|c|c|c|c|}
\hline \multirow[t]{3}{*}{$\overline{\text { Year }}$} & \multicolumn{10}{|c|}{ Population brackets } \\
\hline & Below & $1,000-$ & $3,000-$ & $5,000-$ & $10,000-$ & $30,000-$ & $50,000-$ & $100,000-$ & $250,000-$ & Above \\
\hline & 1,000 & 3,000 & 5,000 & 10,000 & 30,000 & 50,000 & 100,000 & 250,000 & 500,000 & 500,000 \\
\hline$\overline{1993}$ & 1,227 & 1,227 & 1,841 & 2,455 & 2,455 & 2,762 & 3,375 & 3,989 & 4,603 & 6,137 \\
\hline 1994 & 1,306 & 1,306 & 1,959 & 2,612 & 2,612 & 2,939 & 3,592 & 4,245 & 4,898 & 6,531 \\
\hline 1995 & 1,240 & 1,240 & 1,860 & 2,480 & 2,480 & 2,790 & 3,410 & 4,030 & 4,650 & 6,200 \\
\hline 1996 & 1,190 & 1,190 & 1,785 & 2,381 & 2,381 & 2,678 & 3,273 & 3,869 & 4,464 & 5,952 \\
\hline 1997 & 1,286 & 1,286 & 1,929 & 2,571 & 2,571 & 2,893 & 3,536 & 4,178 & 4,821 & 6,428 \\
\hline 1998 & 1,262 & 1,262 & 1,892 & 2,523 & 2,523 & 2,838 & 3,469 & 4,100 & 4,731 & 6,308 \\
\hline 1999 & 1,241 & 1,241 & 1,861 & 2,482 & 2,482 & 2,792 & 3,412 & 4,033 & 4,653 & 6,204 \\
\hline 2000 & 1,291 & 1,446 & 2,169 & 2,789 & 3,099 & 3,460 & 4,132 & 5,010 & 5,784 & 7,798 \\
\hline 2001 & 1,256 & 1,407 & 2,110 & 2,713 & 3,014 & 3,366 & 4,019 & 4,873 & 5,627 & 7,586 \\
\hline 2002 & 1,226 & 1,373 & 2,060 & 2,648 & 2,943 & 3,286 & 3,924 & 4,757 & 5,493 & 7,406 \\
\hline 2003 & 1,291 & 1,446 & 2,169 & 2,789 & 3,099 & 3,460 & 4,132 & 5,010 & 5,784 & 7,798 \\
\hline 2004 & 1,263 & 1,415 & 2,122 & 2,728 & 3,031 & 3,385 & 4,042 & 4,901 & 5,659 & 7,629 \\
\hline
\end{tabular}

Notes. Population is the number of resident inhabitants as measured by the last available Census. The real monthly salary is computed using the OECD CPI index.

Table 2: Legislative thresholds for Italian municipalities

\begin{tabular}{lcccccccc}
\hline \hline Population & $\begin{array}{c}\text { Wage } \\
\text { Mayor }\end{array}$ & $\begin{array}{c}\text { Wage } \\
\text { Ex. Com. }\end{array}$ & $\begin{array}{c}\text { Fiche } \\
\text { Council }\end{array}$ & $\begin{array}{c}\text { Ex. Com. } \\
\text { Size }\end{array}$ & $\begin{array}{c}\text { Council } \\
\text { Size }\end{array}$ & $\begin{array}{c}\text { Electoral } \\
\text { Rule }\end{array}$ & $\begin{array}{c}\text { Neighbor. } \\
\text { Councils }\end{array}$ & $\begin{array}{c}\text { Stability } \\
\text { Pact }\end{array}$ \\
\hline Below 1,000 & 1,291 & $15 \%$ & 18 & 4 & 12 & single & no & no \\
$1,000-3,000$ & 1,446 & $20 \%$ & 18 & 4 & 12 & single & no & no \\
$3,000-5,000$ & 2,169 & $20 \%$ & 18 & 4 & 16 & single & no & no \\
$5,000-10,000$ & 2,789 & $50 \%$ & 18 & 4 & 16 & single & no & since 2002 \\
$10,000-15,000$ & 3,099 & $55 \%$ & 22 & 6 & 20 & single & no & since 2002 \\
$15,000-30,000$ & 3,099 & $55 \%$ & 22 & 6 & 20 & runoff & no & since 2002 \\
$30,000-50,000$ & 3,460 & $55 \%$ & 36 & 6 & 30 & runoff & allowed & since 2002 \\
$50,000-100,000$ & 4,132 & $75 \%$ & 36 & 6 & 30 & runoff & allowed & since 2002 \\
$100,000-250,000$ & 5,010 & $75 \%$ & 36 & 10 & 40 & runoff & yes & since 2002 \\
$250,000-500,000$ & 5,784 & $75 \%$ & 36 & 12 & 46 & runoff & yes & since 2002 \\
Above 500,000 & 7,798 & $75 \%$ & 36 & $14-16$ & $50-60$ & runoff & yes & since 2002 \\
\hline \hline
\end{tabular}

Notes. Population is the number of resident inhabitants as measured by the last available Census. Wage Mayor and Wage Ex. Com. refer to the monthly gross wage of the mayor and the members of the executive committee, respectively; the latter is expressed as a percentage of the former, which refers to 2000 and is measured in euros. Fiche Council is the reimbursement per session paid to councillors and is measured in euros. The wage thresholds at 1,000 and 10,000 were introduced in 2000; all of the others date back to 1960. Ex. Com. Size is the maximum allowed number of executives appointed by the mayor. Council Size is the number of seats in the City Council. All of the size thresholds were set in 1960. Since 1993, Electoral Rule can be either single round (with $60 \%$ premium) or runoff (with $66 \%$ premium) plurality voting. Neighborhood Councils are bodies that represent different neighborhoods within the city and are provided with independent budgets. Stability Pact refers to a set of rules decided by the central government to impose fiscal discipline on local authorities. 
Table 3: Population distribution

\begin{tabular}{lcc}
\hline \hline Population & 1991 Census & 2001 Census \\
\hline Below 1,000 & 1,913 & 1,892 \\
& $(24.04)$ & $(24.44)$ \\
$1,000-3,000$ & 2,665 & 2,542 \\
& $(33.50)$ & $(32.84)$ \\
$3,000-5,000$ & 1,202 & 1,156 \\
& $(15.11)$ & $(14.93)$ \\
$5,000-10,000$ & 1,145 & 1,115 \\
& $(14.39)$ & $(14.40)$ \\
$10,000-15,000$ & 406 & 427 \\
& $(5.10)$ & $(5.52)$ \\
$15,000-30,000$ & 344 & 343 \\
& $(4.32)$ & $(4.43)$ \\
$30,000-50,000$ & 146 & 141 \\
& $(1.84)$ & $(1.82)$ \\
$50,000-100,000$ & 90 & 85 \\
& $(1.13)$ & $(1.10)$ \\
$100,000-250,000$ & 33 & 27 \\
& $(0.41)$ & $(0.35)$ \\
$250,000-500,000$ & 6 & 7 \\
& $(0.08)$ & $(0.09)$ \\
Above 500,000 & 6 & 6 \\
& $(0.08)$ & $(0.08)$ \\
\hline Total & 7,956 & 7,741 \\
\hline \hline Notes. Population is the number of resident inhabitants as measured by \\
the last available Census. Percentage values in parentheses.
\end{tabular}


Table 4: Characteristics of candidates and elected mayors

\begin{tabular}{|c|c|c|c|c|c|c|}
\hline Population & Female & Age & $\begin{array}{c}\text { Years of } \\
\text { schooling }\end{array}$ & $\begin{array}{c}\text { Not } \\
\text { employed }\end{array}$ & $\begin{array}{l}\text { High-skilled } \\
\text { occupation }\end{array}$ & $\begin{array}{l}\text { Low-skilled } \\
\text { occupation }\end{array}$ \\
\hline \multicolumn{7}{|c|}{ All candidates } \\
\hline Below 1,000 & 0.07 & 47.00 & 12.24 & 0.19 & 0.30 & 0.30 \\
\hline $1,000-3,000$ & 0.07 & 46.26 & 13.58 & 0.15 & 0.42 & 0.21 \\
\hline $3,000-5,000$ & 0.06 & 46.27 & 14.06 & 0.13 & 0.49 & 0.18 \\
\hline $5,000-10,000$ & 0.08 & 46.22 & 14.36 & 0.12 & 0.52 & 0.16 \\
\hline $10,000-15,000$ & 0.07 & 46.68 & 14.81 & 0.09 & 0.55 & 0.15 \\
\hline $15,000-30,000$ & 0.07 & 47.17 & 15.09 & 0.08 & 0.61 & 0.13 \\
\hline $30,000-50,000$ & 0.07 & 47.43 & 15.43 & 0.06 & 0.63 & 0.10 \\
\hline $50,000-100,000$ & 0.05 & 49.16 & 15.81 & 0.05 & 0.71 & 0.09 \\
\hline Above 100,000 & 0.08 & 51.75 & 15.80 & 0.08 & 0.74 & 0.05 \\
\hline Total & 0.07 & 46.59 & 13.76 & 0.14 & 0.45 & 0.20 \\
\hline Obs. & 31,822 & 31,822 & 31,822 & 31,822 & 31,822 & 31,822 \\
\hline \multicolumn{7}{|c|}{ Elected mayors } \\
\hline Below 1,000 & 0.06 & 47.60 & 12.38 & 0.18 & 0.31 & 0.28 \\
\hline $1,000-3,000$ & 0.06 & 46.43 & 13.74 & 0.13 & 0.45 & 0.19 \\
\hline $3,000-5,000$ & 0.06 & 46.44 & 14.22 & 0.11 & 0.50 & 0.15 \\
\hline $5,000-10,000$ & 0.08 & 45.98 & 14.48 & 0.10 & 0.53 & 0.14 \\
\hline $10,000-15,000$ & 0.06 & 46.45 & 14.99 & 0.07 & 0.58 & 0.13 \\
\hline $15,000-30,000$ & 0.06 & 46.75 & 15.16 & 0.06 & 0.59 & 0.13 \\
\hline $30,000-50,000$ & 0.05 & 47.12 & 15.44 & 0.03 & 0.63 & 0.10 \\
\hline $50,000-100,000$ & 0.05 & 48.10 & 15.87 & 0.04 & 0.70 & 0.09 \\
\hline Above 100,000 & 0.08 & 51.93 & 15.82 & 0.05 & 0.75 & 0.03 \\
\hline Total & 0.07 & 46.73 & 13.80 & 0.12 & 0.46 & 0.19 \\
\hline Obs. & 16,393 & 16,393 & 16,393 & 16,393 & 16,393 & 16,393 \\
\hline
\end{tabular}

Notes. Population is the number of resident inhabitants, as measured by the last Census. The other columns report average values. All variables are dummies, except Age and Years of schooling (both measured in years). Years of schooling is the number of years needed to complete the highest degree obtained. Not employed includes unemployed, retired, and any other individual out of the labor force. High-skilled occupation includes lawyers, professors, physicians, self-employed, and entrepreneurs. Low-skilled occupation includes blue collars, clerks, and technicians. Other types of occupation in the residual category. Terms from 1993 to 2001. 
Table 5: Budget performance

\begin{tabular}{|c|c|c|c|c|c|c|c|c|c|c|c|}
\hline \multirow[t]{2}{*}{ Population } & \multirow[t]{2}{*}{ Deficit } & \multicolumn{4}{|c|}{ Expenditure } & \multicolumn{4}{|c|}{ Revenues } & \multicolumn{2}{|c|}{ Efficiency } \\
\hline & & Total & Investments & $\begin{array}{l}\text { Personnel } \\
\text { and debt }\end{array}$ & $\begin{array}{c}\text { Goods and } \\
\text { services }\end{array}$ & Total & Transfers & Taxes & Tariffs & $\begin{array}{l}\text { Speed of } \\
\text { collection }\end{array}$ & $\begin{array}{l}\text { Speed of } \\
\text { payment }\end{array}$ \\
\hline Below 1,000 & 27.00 & $2,068.17$ & $1,010.55$ & 593.96 & 465.75 & $2,041.17$ & $1,555.41$ & 280.05 & 205.70 & 65.93 & 80.06 \\
\hline $1,000-3,000$ & 17.21 & $1,325.88$ & 547.10 & 379.57 & 399.70 & $1,308.66$ & 924.39 & 242.43 & 141.85 & 65.66 & 80.36 \\
\hline $3,000-5,000$ & 20.22 & $1,134.89$ & 416.51 & 322.63 & 395.75 & $1,114.67$ & 732.24 & 246.93 & 135.49 & 65.32 & 79.45 \\
\hline $5,000-10,000$ & 13.57 & $1,026.93$ & 310.14 & 303.99 & 412.79 & $1,013.36$ & 603.30 & 274.93 & 135.12 & 65.26 & 78.49 \\
\hline $10,000-15,000$ & 18.94 & $1,075.52$ & 302.45 & 315.50 & 457.58 & $1,056.59$ & 617.49 & 291.65 & 147.44 & 65.09 & 78.14 \\
\hline $15,000-30,000$ & 18.39 & $1,072.24$ & 279.52 & 316.40 & 476.33 & $1,053.85$ & 600.47 & 299.92 & 153.46 & 65.43 & 77.47 \\
\hline $30,000-50,000$ & 17.72 & $1,083.36$ & 262.64 & 332.95 & 487.78 & $1,065.64$ & 613.81 & 313.70 & 138.12 & 63.65 & 75.58 \\
\hline $50,000-100,000$ & 23.53 & $1,272.23$ & 327.46 & 377.95 & 566.82 & $1,248.70$ & 763.53 & 324.93 & 160.24 & 62.31 & 75.19 \\
\hline Above 100,000 & 25.65 & $1,587.29$ & 419.17 & 465.25 & 702.87 & $1,561.64$ & 980.50 & 407.52 & 173.62 & 66.69 & 76.32 \\
\hline Total & 19.74 & $1,401.93$ & 570.01 & 404.30 & 428.28 & $1,382.20$ & 961.07 & 264.98 & 156.15 & 65.51 & 79.47 \\
\hline Obs. & 14,115 & 14,115 & 14,115 & 14,115 & 14,115 & 14,115 & 14,115 & 14,115 & 14,115 & 14,115 & 14,115 \\
\hline
\end{tabular}

Notes. Population is the number of resident inhabitants, as mesured by the last Census. The other colums report average values. All budget variables (i.e., deficit, types of expen and types of revenues) are in per-capita terms, expressed in euros at 2000 prices, and averaged over the mayoral term (election years excluded). The Transfers variable refers to external transfers from the central government, the regional government, or the European Union. The Efficiency measures are expressed in percentage points: Speed of collection is the ratio between collected and assessed revenues; Speed of payment is the ratio between paid and committed outlays for public expenditure. Terms from 1993 to 2001. 
Table 6: Balance tests of town characteristics

\begin{tabular}{lccc}
\hline \hline & Area & North/South & $\begin{array}{c}\text { Center-right } \\
\text { party }\end{array}$ \\
\hline Discontinuity & 5.866 & Bandwidth: 125 & -0.194 \\
& $(17.904)$ & $(0.211)$ & -0.010 \\
\hline \multirow{3}{*}{ Discontinuity } & 6.983 & Bandwidth: 150 & $(0.038)$ \\
& $(15.144)$ & $(0.195)$ & 0.005 \\
Discontinuity & 9.905 & Bandwidth: 175 \\
& $(13.759)$ & -0.199 & $0.047)$ \\
\hline Obs. & 1,488 & $1,48)$ & $(0.051)$ \\
\hline \hline
\end{tabular}

Notes. Discontinuity of town characteristics at the 5,000 threshold Weighted kernel estimation on both sides of the threshold, with binsize equal to 10 and bandwidth as specified. Terms from 1993 to 2001; cities with population between 3,250 and 6,750 inhabitants. Area is measured in $\mathrm{km}^{2}$. North/South is a dummy equal to 1 for Piemonte, Lombardia, Val d'Aosta, Veneto, Friuli-Venezia-Giulia, Trentino Alto-Adige, Veneto, Liguria and Emilia-Romagna, and 0 otherwise. Bootstrapped standard errors (200 replications) are in parentheses. Significance at the $10 \%$ level is represented by $*$, at the $5 \%$ level by $* *$, and at the $1 \%$ level by $* * *$. 
Table 7: Candidate selection, RDD estimates

\begin{tabular}{|c|c|c|c|c|c|c|}
\hline Population & Female & Age & $\begin{array}{l}\text { Years of } \\
\text { schooling }\end{array}$ & $\begin{array}{c}\text { Not } \\
\text { employed }\end{array}$ & $\begin{array}{l}\text { High-skilled } \\
\text { occupation }\end{array}$ & $\begin{array}{l}\text { Low-skilled } \\
\text { occupation }\end{array}$ \\
\hline \multicolumn{7}{|c|}{ LLR with optimal bandwidth } \\
\hline \multirow[t]{2}{*}{ Effect } & 0.005 & -0.951 & $0.905^{* * *}$ & -0.021 & 0.048 & -0.018 \\
\hline & $(0.018)$ & $(0.608)$ & $(0.279)$ & $(0.024)$ & $(0.034)$ & $(0.025)$ \\
\hline$\Delta$ & 1,300 & 1,600 & 900 & 1,000 & 1,500 & 1,400 \\
\hline Obs. & 4,805 & 5,953 & 3,295 & 3,758 & 5,581 & 5,191 \\
\hline \multicolumn{7}{|c|}{ LLR with half optimal bandwidth } \\
\hline \multirow[t]{2}{*}{ Effect } & 0.017 & -0.664 & $1.012^{* *}$ & -0.032 & $0.092^{*}$ & -0.043 \\
\hline & $(0.025)$ & $(0.848)$ & $(0.424)$ & $(0.034)$ & $(0.050)$ & $(0.035)$ \\
\hline$\Delta$ & 650 & 800 & 450 & 500 & 750 & 700 \\
\hline Obs. & 2,373 & 3,064 & 1,637 & 1,851 & 2,728 & 2,575 \\
\hline \multicolumn{7}{|c|}{ Split polynomial approximation } \\
\hline \multirow[t]{2}{*}{ Effect } & -0.000 & -0.257 & $1.205^{* * *}$ & -0.047 & $0.162^{* *}$ & -0.074 \\
\hline & $(0.030)$ & $(1.168)$ & $(0.415)$ & $(0.035)$ & $(0.067)$ & $(0.045)$ \\
\hline Obs. & 6,544 & 6,544 & 6,544 & 6,544 & 6,544 & 6,544 \\
\hline
\end{tabular}

Notes. Effect of the $33 \%$ wage increase at the 5,000 threshold on the characteristics of the three best candidates. Terms from 1993 to 2001. First estimate: Local Linear Regression (LLR) as in equation (6); the optimal symmetric bandwidth $\Delta$ is chosen with cross-validation methods. Second estimate: LLR with half optimal bandwidth. Third estimate: $3^{\text {rd }}$ order polynomial approximation on either side of the threshold as in equation (7); the maximum symmetric bandwidth is 1,750 . Age and Years of schooling are measured in years; the other variables are dummies. Not employed includes unemployed, retired, and any other individual out of the labor force. High-skilled occupation includes lawyers, professors, physicians, selfemployed, and entrepreneurs. Low-skilled occupation includes blue collars, clerks, and technicians. Other types of occupation in the residual category. Standard errors robust to clustering at the municipality level are in parentheses. Significance at the $10 \%$ level is represented by $*$, at the $5 \%$ level by $* *$, and at the $1 \%$ level by $* * *$. 
Table 8: Mayor selection, RDD estimates

\begin{tabular}{lcccccc}
\hline \hline Population & Female & Age & $\begin{array}{c}\text { Years of } \\
\text { schooling }\end{array}$ & $\begin{array}{c}\text { Not } \\
\text { employed }\end{array}$ & $\begin{array}{c}\text { High-skilled } \\
\text { occupation }\end{array}$ & $\begin{array}{c}\text { Low-skilled } \\
\text { occupation }\end{array}$ \\
\hline Effect & -0.012 & -0.746 & $0.879^{* *}$ & 0.002 & 0.108 & -0.035 \\
& $(0.034)$ & $(1.127)$ & $(0.346)$ & $(0.031)$ & $(0.066)$ & $(0.035)$ \\
$\Delta$ & 800 & 900 & 1,100 & 1,200 & 800 & 1,400 \\
Obs. & 1,340 & 1,531 & 1,905 & 2,053 & 1,340 & 2,396 \\
\hline Effect & 0.032 & -0.485 & $1.174^{* *}$ & -0.028 & $0.162^{*}$ & -0.062 \\
& $(0.042)$ & $(1.658)$ & $(0.504)$ & $(0.043)$ & $(0.094)$ & $(0.050)$ \\
$\Delta$ & 400 & 450 & 550 & 600 & 400 & 700 \\
Obs. & 692 & 759 & 913 & 999 & 692 & 1,187 \\
\hline \multirow{7}{*}{ Split polynomial approximation } \\
Effect & 0.015 & -0.006 & $1.633^{* * *}$ & -0.057 & $0.217^{* *}$ & -0.083 \\
Obs. & $(0.043)$ & $(1.631)$ & $(0.558)$ & $(0.050)$ & $(0.090)$ & $(0.064)$ \\
\hline \hline
\end{tabular}

Notes. Effect of the 33\% wage increase at the 5,000 threshold on the characteristics of the elected mayor. Terms from 1993 to 2001. First estimate: Local Linear Regression (LLR) as in equation (6); the optimal symmetric bandwidth $\Delta$ is chosen with cross-validation methods. Second estimate: LLR with half optimal bandwidth. Third estimate: $3^{\text {rd }}$ order polynomial approximation on either side of the threshold as in equation (7); the maximum symmetric bandwidth is 1,750 . Age and Years of schooling are measured in years; the other variables are dummies. Not employed includes unemployed, retired, and any other individual out of the labor force. High-skilled occupation includes lawyers, professors, physicians, self-employed, and entrepreneurs. Low-skilled occupation includes blue collars, clerks, and technicians. Other types of occupation in the residual category. Standard errors robust to clustering at the municipality level are in parentheses. Significance at the $10 \%$ level is represented by $*$, at the $5 \%$ level by ${ }^{* *}$, and at the $1 \%$ level by $* * *$. 
Table 9: Candidate and mayor selection, robustness exercise

\begin{tabular}{lcccccc}
\hline \hline Population & Female & Age & $\begin{array}{c}\text { Years of } \\
\text { schooling }\end{array}$ & $\begin{array}{c}\text { Not } \\
\text { employed }\end{array}$ & $\begin{array}{c}\text { High-skilled } \\
\text { occupation }\end{array}$ & $\begin{array}{c}\text { Low-skilled } \\
\text { occupation }\end{array}$ \\
\hline All candidates \\
Effect & 0.009 & -0.931 & $0.846^{* * *}$ & -0.017 & 0.035 & -0.010 \\
& $(0.017)$ & $(0.604)$ & $(0.271)$ & $(0.024)$ & $(0.034)$ & $(0.024)$ \\
$\Delta$ & 1,300 & 1,600 & 900 & 1,000 & 1,500 & 1,400 \\
Obs. & 4,805 & 5,953 & 3,295 & 3,758 & 5,581 & 5,191 \\
\hline \multicolumn{7}{c}{ Mayors } \\
\hline Effect & -0.009 & -0.730 & $0.796^{* *}$ & 0.005 & 0.102 & -0.028 \\
$\Delta$ & $(0.033)$ & $(1.117)$ & $(0.342)$ & $(0.031)$ & $(0.065)$ & $(0.035)$ \\
Obs. & 800 & 900 & 1,100 & 1,200 & 800 & 1,400 \\
\hline \hline
\end{tabular}

Notes. Effect of the $33 \%$ wage increase at the 5,000 threshold on the characteristics of the three best candidates (top panel) or of the elected mayor (bottom panel). Terms from 1993 to 2001. Local Linear Regression (LLR) as in equation (6), with optimal bandwidth $\Delta$ and invariant town characteristics (Area in $\mathrm{km}^{2}$ and North/South dummy) as additional covariates. Age and Years of schooling are measured in years; the other variables are dummies. Not employed includes unemployed, retired, and any other individual out of the labor force. High-skilled occupation includes lawyers, professors, physicians, self-employed, and entrepreneurs. Low-skilled occupation includes blue collars, clerks, and technicians. Other types of occupation in the residual category. Standard errors robust to clustering at the municipality level are in parentheses. Significance at the $10 \%$ level is represented by $*$, at the $5 \%$ level by **, and at the $1 \%$ level by ***. 
Table 10: Candidate and mayor selection, placebo tests

\begin{tabular}{|c|c|c|c|c|c|c|}
\hline Population & Female & Age & $\begin{array}{l}\text { Years of } \\
\text { schooling }\end{array}$ & $\begin{array}{c}\text { Not } \\
\text { employed }\end{array}$ & $\begin{array}{l}\text { High-skilled } \\
\text { occupation }\end{array}$ & $\begin{array}{l}\text { Low-skilled } \\
\text { occupation }\end{array}$ \\
\hline \multicolumn{7}{|c|}{ All candidates } \\
\hline \multicolumn{7}{|c|}{ Split polynomial approximation, median above $(5,956)$} \\
\hline \multirow[t]{2}{*}{ Effect } & 0.008 & 0.865 & -0.082 & -0.009 & -0.139 & $0.146^{* *}$ \\
\hline & $(0.045)$ & $(1.955)$ & $(0.627)$ & $(0.057)$ & $(0.096)$ & $(0.058)$ \\
\hline \multirow[t]{2}{*}{ Obs. } & 2,072 & 2,072 & 2,072 & 2,072 & 2,072 & 2,072 \\
\hline & \multicolumn{6}{|c|}{ Split polynomial approximation, median below $(3,985)$} \\
\hline \multirow[t]{2}{*}{ Effect } & 0.000 & -1.350 & 0.029 & -0.012 & -0.013 & 0.022 \\
\hline & $(0.033)$ & $(1.601)$ & $(0.503)$ & $(0.050)$ & $(0.079)$ & $(0.068)$ \\
\hline Obs. & 3,555 & 3,555 & 3,555 & 3,555 & 3,555 & 3,555 \\
\hline \multicolumn{7}{|c|}{ Mayors } \\
\hline \multicolumn{7}{|c|}{ Split polynomial approximation, median above $(5,950)$} \\
\hline \multirow[t]{2}{*}{ Effect } & -0.100 & 2.111 & 0.902 & -0.041 & 0.022 & 0.111 \\
\hline & $(0.089)$ & $(2.562)$ & $(0.839)$ & $(0.074)$ & $(0.146)$ & $(0.081)$ \\
\hline \multirow[t]{2}{*}{ Obs. } & 936 & 936 & 936 & 936 & 936 & 936 \\
\hline & \multicolumn{6}{|c|}{ Split polynomial approximation, median below $(3,975)$} \\
\hline Effect & -0.018 & 2.203 & -0.177 & -0.020 & -0.137 & 0.085 \\
\hline & $(0.036)$ & $(2.274)$ & $(0.663)$ & $(0.076)$ & $(0.114)$ & $(0.085)$ \\
\hline Obs. & 1,678 & 1,678 & 1,678 & 1,678 & 1,678 & 1,678 \\
\hline
\end{tabular}

Notes. Estimated discontinuities in the characteristics of the three best candidates (top panel) or of the elected mayor (bottom panel) at fake thresholds (i.e, median above and below the true 5,000 threshold). Terms elected from 1993 to 2001. Estimates computed with a $3^{\text {rd }}$ order polynomial approximation on either side of the threshold as in equation (7). Age and Years of schooling are measured in years; the other variables are dummies. Not employed includes unemployed, retired, and any other individual out of the labor force. High-skilled occupation includes lawyers, professors, physicians, self-employed, and entrepreneurs. Low-skilled occupation includes blue collars, clerks, and technicians. Other types of occupation in the residual category. Standard errors robust to clustering at the municipality level are in parentheses. Significance at the $10 \%$ level is represented by $*$, at the $5 \%$ level by ${ }^{* *}$, and at the $1 \%$ level by $* * *$. 
Table 11: Budget components per capita, RDD estimates

\begin{tabular}{|c|c|c|c|c|c|c|c|c|c|}
\hline & \multirow[t]{2}{*}{ Deficit } & \multicolumn{4}{|c|}{ Expenditure } & \multicolumn{4}{|c|}{ Revenues } \\
\hline & & Total & Investments & $\begin{array}{l}\text { Personnel } \\
\text { and debt }\end{array}$ & $\begin{array}{c}\text { Goods and } \\
\text { services }\end{array}$ & Total & Transfers & Taxes & Tariffs \\
\hline & \multicolumn{9}{|c|}{ LLR with optimal bandwidth } \\
\hline A. Overall $(\mathrm{TL}=0)$ & $\begin{array}{l}-1.865 \\
(8.467)\end{array}$ & $\begin{array}{c}-228.033^{* * *} \\
(68.072)\end{array}$ & $\begin{array}{l}-60.620 \\
(50.965)\end{array}$ & $\begin{array}{c}-35.754^{* *} \\
(16.094)\end{array}$ & $\begin{array}{c}-86.455^{* * *} \\
(25.596)\end{array}$ & $\begin{array}{c}-223.187^{* * *} \\
(67.977)\end{array}$ & $\begin{array}{l}-17.272 \\
(65.748)\end{array}$ & $\begin{array}{l}-31.805^{*} \\
(17.319)\end{array}$ & $\begin{array}{c}-121.854^{* * *} \\
(42.225)\end{array}$ \\
\hline B. Composition $(\mathrm{TL}=1)$ & $\begin{array}{c}1.889 \\
(4.334)\end{array}$ & $\begin{array}{c}-240.415^{* * *} \\
(79.917)\end{array}$ & $\begin{array}{l}-78.392^{*} \\
(46.457)\end{array}$ & $\begin{array}{l}-32.141 \\
(22.230)\end{array}$ & $\begin{array}{c}-95.301 * * * \\
(22.781)\end{array}$ & $\begin{array}{c}-243.303^{* * *} \\
(81.588)\end{array}$ & $\begin{array}{l}-46.472 \\
(53.795)\end{array}$ & $\begin{array}{c}-37.947^{* *} \\
(17.567)\end{array}$ & $\begin{array}{c}-116.855^{* * *} \\
(44.992)\end{array}$ \\
\hline C. Incentive (A-B) & $\begin{array}{l}-3.754 \\
(8.508)\end{array}$ & $\begin{array}{c}12.383 \\
(51.926)\end{array}$ & $\begin{array}{l}17.773 \\
(50.056)\end{array}$ & $\begin{array}{c}-3.613 \\
(18.836)\end{array}$ & $\begin{array}{c}8.846 \\
(15.357)\end{array}$ & $\begin{array}{c}20.116 \\
(50.558)\end{array}$ & $\begin{array}{c}29.200 \\
(63.103)\end{array}$ & $\begin{array}{c}6.142 \\
(8.120)\end{array}$ & $\begin{array}{c}-4.999 \\
(19.529)\end{array}$ \\
\hline$\Delta$ & 1,200 & 1,000 & 1,500 & 1,100 & 1,500 & 1,000 & 1,400 & 1,400 & 1,100 \\
\hline Obs. & 816 & 696 & 1,016 & 758 & 1,016 & 696 & 950 & 950 & 758 \\
\hline & \multicolumn{9}{|c|}{ LLR with half optimal bandwidth } \\
\hline A. Overall $(\mathrm{TL}=0)$ & $\begin{array}{l}-7.222 \\
(9.852)\end{array}$ & $\begin{array}{l}-197.823^{*} \\
(100.758)\end{array}$ & $\begin{array}{c}-109.295^{* *} \\
(53.738)\end{array}$ & $\begin{array}{c}-34.090^{*} \\
(19.286)\end{array}$ & $\begin{array}{c}-69.452^{*} \\
(36.324)\end{array}$ & $\begin{array}{c}-188.134^{*} \\
(102.562)\end{array}$ & $\begin{array}{l}-68.956 \\
(64.780)\end{array}$ & $\begin{array}{l}-20.206 \\
(23.062)\end{array}$ & $\begin{array}{r}-107.796 \\
(66.880)\end{array}$ \\
\hline B. Composition $(\mathrm{TL}=1)$ & $\begin{array}{c}20.111^{* * *} \\
(6.905)\end{array}$ & $\begin{array}{l}-247.372^{*} \\
(128.486)\end{array}$ & $\begin{array}{c}-134.606^{* *} \\
(67.630)\end{array}$ & $\begin{array}{l}-13.161 \\
(30.676)\end{array}$ & $\begin{array}{c}-76.602^{* *} \\
(30.422)\end{array}$ & $\begin{array}{l}-261.207^{*} \\
(132.419)\end{array}$ & $\begin{array}{l}-106.596 \\
(76.243)\end{array}$ & $\begin{array}{l}-26.027 \\
(23.505)\end{array}$ & $\begin{array}{l}-131.903 \\
(82.831)\end{array}$ \\
\hline C. Incentive (A-B) & $\begin{array}{c}-27.333^{* * *} \\
(10.000)\end{array}$ & $\begin{array}{c}49.549 \\
(75.272)\end{array}$ & $\begin{array}{c}25.311 \\
(53.211)\end{array}$ & $\begin{array}{l}-20.929 \\
(25.026)\end{array}$ & $\begin{array}{c}7.150 \\
(21.671)\end{array}$ & $\begin{array}{c}73.072 \\
(74.054)\end{array}$ & $\begin{array}{l}37.640 \\
(52.293)\end{array}$ & $\begin{array}{c}5.821 \\
(10.699)\end{array}$ & $\begin{array}{c}24.107 \\
(25.817)\end{array}$ \\
\hline$\Delta$ & 600 & 500 & 750 & 550 & 750 & 500 & 700 & 700 & 550 \\
\hline Obs. & 404 & 348 & 510 & 370 & 510 & 348 & 484 & 484 & 370 \\
\hline & \multicolumn{9}{|c|}{ Split polynomial approximation } \\
\hline A. Overall $(\mathrm{TL}=0)$ & $\begin{array}{c}-8.171 \\
(11.020)\end{array}$ & $\begin{array}{c}-210.952^{*} \\
(117.022)\end{array}$ & $\begin{array}{l}-68.139 \\
(80.653)\end{array}$ & $\begin{array}{l}-42.855 \\
(28.933)\end{array}$ & $\begin{array}{c}-99.959 * * \\
(50.839)\end{array}$ & $\begin{array}{c}-202.782^{*} \\
(118.113)\end{array}$ & $\begin{array}{l}-59.677 \\
(94.985)\end{array}$ & $\begin{array}{l}-21.760 \\
(31.015)\end{array}$ & $\begin{array}{c}-121.345^{*} \\
(73.385)\end{array}$ \\
\hline B. Composition $(\mathrm{TL}=1)$ & $\begin{array}{l}14.075^{*} \\
(7.841)\end{array}$ & $\begin{array}{c}-254.564^{* *} \\
(128.265)\end{array}$ & $\begin{array}{c}-159.246^{*} \\
(89.964)\end{array}$ & $\begin{array}{l}-17.092 \\
(33.567)\end{array}$ & $\begin{array}{c}-78.226^{* *} \\
(39.032)\end{array}$ & $\begin{array}{c}-268.639^{* *} \\
(132.183)\end{array}$ & $\begin{array}{l}-100.668 \\
(84.790)\end{array}$ & $\begin{array}{l}-23.059 \\
(30.779)\end{array}$ & $\begin{array}{l}-144.912 \\
(92.585)\end{array}$ \\
\hline C. Incentive (A-B) & $\begin{array}{c}-22.246^{* *} \\
(11.153)\end{array}$ & $\begin{array}{c}43.611 \\
(94.144)\end{array}$ & $\begin{array}{c}91.108 \\
(89.237)\end{array}$ & $\begin{array}{l}-25.763 \\
(32.437)\end{array}$ & $\begin{array}{l}-21.733 \\
(30.088)\end{array}$ & $\begin{array}{c}65.857 \\
(92.775)\end{array}$ & $\begin{array}{c}40.991 \\
(84.318)\end{array}$ & $\begin{array}{c}1.299 \\
(13.437)\end{array}$ & $\begin{array}{c}23.567 \\
(27.919)\end{array}$ \\
\hline Obs. & 1,194 & 1,194 & 1,194 & 1,194 & 1,194 & 1,194 & 1,194 & 1,194 & 1,194 \\
\hline
\end{tabular}

Notes. Effect of the 33\% wage increase at the 5,000 threshold on budget variables. Terms from 1993 to 2001; only mayors observed for two terms, with binding term limit in the second. First estimate: Local Linear Regression (LLR) as in equation (8); the optimal symmetric bandwidth $\Delta$ is chosen with cross-validation methods. Second estimate: LLR with half optimal bandwidth. Third estimate: $3^{\text {rd }}$ order polynomial approximation on either side of the threshold as in equation (9); the maximum symmetric bandwidth is 1,750 . All variables are in per-capita terms, expressed in euros at 2000 prices, and averaged over the mayoral term (election years excluded). TL is an index for the term limit. Standard errors robust to clustering at the municipality level are in parentheses. Significance at the $10 \%$ level is represented by *, at the $5 \%$ level by **, and at the $1 \%$ level by ***. 
Table 12: Budget components per capita, robustness exercises

\begin{tabular}{|c|c|c|c|c|c|c|c|c|c|}
\hline & \multirow[t]{2}{*}{ Deficit } & \multicolumn{4}{|c|}{ Expenditure } & \multicolumn{4}{|c|}{ Revenues } \\
\hline & & Total & Investments & $\begin{array}{c}\text { Personnel } \\
\text { and debt }\end{array}$ & $\begin{array}{c}\text { Goods and } \\
\text { services }\end{array}$ & Total & Transfers & Taxes & Tariffs \\
\hline & \multicolumn{9}{|c|}{ LLR with optimal bandwidth for contestable cities } \\
\hline \multirow[t]{2}{*}{ A. Overall $(\mathrm{TL}=0)$} & -10.414 & $-244.237^{* *}$ & -72.462 & -46.011 & $-133.215^{* * *}$ & $-229.152^{* *}$ & 5.003 & -22.859 & $-182.397^{* * *}$ \\
\hline & $(9.011)$ & $(94.823)$ & $(63.425)$ & $(34.163)$ & $(42.694)$ & $(95.379)$ & $(69.563)$ & $(20.164)$ & $(68.072)$ \\
\hline \multirow[t]{2}{*}{ B. Composition $(\mathrm{TL}=1)$} & 1.852 & $-220.730^{*}$ & -84.488 & -26.279 & $-115.432^{* * *}$ & $-224.483^{*}$ & 3.420 & -31.517 & $-172.851^{* *}$ \\
\hline & $(5.367)$ & $(112.085)$ & $(79.780)$ & $(31.773)$ & $(35.288)$ & $(114.922)$ & $(83.142)$ & $(21.648)$ & $(70.846)$ \\
\hline \multirow[t]{2}{*}{ C. Incentive (A-B) } & -12.266 & -23.507 & 12.026 & -19.733 & -17.783 & -4.669 & 1.583 & 8.659 & -9.546 \\
\hline & $(9.058)$ & $(69.898)$ & $(60.538)$ & $(37.515)$ & $(25.293)$ & $(68.365)$ & $(61.423)$ & $(9.547)$ & $(30.724)$ \\
\hline$\Delta$ & 1,400 & 1,100 & 1,100 & 900 & 1,100 & 1,100 & 1,100 & 1,700 & 1,100 \\
\hline \multirow[t]{2}{*}{ Obs. } & 581 & 453 & 453 & 373 & 453 & 453 & 453 & 699 & 453 \\
\hline & \multicolumn{9}{|c|}{ LLR with optimal bandwidth for freshmen after 1993} \\
\hline \multirow[t]{2}{*}{ A. Overall $(\mathrm{TL}=0)$} & -1.700 & $-194.691^{* *}$ & -90.123 & -24.413 & $-63.510^{* *}$ & $-179.994^{*}$ & -82.126 & -16.504 & $-79.816^{* *}$ \\
\hline & $(9.959)$ & $(78.982)$ & $(79.762)$ & $(17.447)$ & $(28.892)$ & $(93.490)$ & $(81.686)$ & $(22.076)$ & $(37.335)$ \\
\hline \multirow[t]{2}{*}{ B. Composition $(\mathrm{TL}=1)$} & -0.835 & $-211.854^{* * *}$ & -78.857 & -25.133 & $-80.898^{* * *}$ & $-186.958^{* *}$ & -101.239 & -18.277 & $-63.586^{* *}$ \\
\hline & $(4.460)$ & $(70.767)$ & $(50.398)$ & $(22.939)$ & $(27.108)$ & $(72.858)$ & $(63.459)$ & $(22.740)$ & $(28.446)$ \\
\hline \multirow[t]{2}{*}{ C. Incentive (A-B) } & -0.865 & 17.163 & -11.265 & 0.720 & 17.388 & 6.965 & 19.113 & 1.774 & -16.230 \\
\hline & $(10.208)$ & $(66.743)$ & $(76.860)$ & $(19.341)$ & $(17.172)$ & $(79.944)$ & $(79.586)$ & $(10.525)$ & $(19.827)$ \\
\hline$\Delta$ & 1,200 & 1,500 & 1,400 & 1,400 & 1,500 & 1,400 & 1,400 & 1,000 & 1,600 \\
\hline \multirow[t]{2}{*}{ Obs. } & 642 & 796 & 746 & 746 & 796 & 746 & 746 & 546 & 848 \\
\hline & \multicolumn{9}{|c|}{ LLR with optimal bandwidth and covariates } \\
\hline \multirow[t]{2}{*}{ A. Overall $(\mathrm{TL}=0)$} & 0.536 & $-199.591^{* * *}$ & -45.437 & $-28.794^{*}$ & $-77.334^{* * *}$ & $-196.206^{* * *}$ & 15.797 & $-32.314^{* *}$ & $-115.519^{* *}$ \\
\hline & $(8.587)$ & $(66.429)$ & $(47.732)$ & $(15.433)$ & $(25.928)$ & $(66.489)$ & $(57.826)$ & $(15.059)$ & $(50.073)$ \\
\hline \multirow[t]{2}{*}{ B. Composition $(\mathrm{TL}=1)$} & 3.807 & $-209.376^{* * *}$ & -61.185 & -26.179 & $-82.791^{* * *}$ & $-213.311^{* * *}$ & -12.936 & $-37.828^{* *}$ & $-107.165^{*}$ \\
\hline & $(4.174)$ & $(80.066)$ & $(46.896)$ & $(22.029)$ & $(22.540)$ & $(81.733)$ & $(49.636)$ & $(15.502)$ & $(56.004)$ \\
\hline \multirow[t]{2}{*}{ C. Incentive (A-B) } & -3.748 & 12.467 & 17.819 & -3.644 & 8.709 & 20.158 & 29.396 & 5.988 & -4.481 \\
\hline & $(8.519)$ & $(51.965)$ & $(50.096)$ & $(18.866)$ & $(15.347)$ & $(50.596)$ & $(63.158)$ & $(8.120)$ & $(21.762)$ \\
\hline$\Delta$ & 1,200 & 1,000 & 1,500 & 1,100 & 1,500 & 1,000 & 1,400 & 1,400 & 1,100 \\
\hline Obs. & 816 & 696 & 1,016 & 758 & 1,016 & 696 & 950 & 950 & 624 \\
\hline
\end{tabular}

Notes. Effect of the $33 \%$ wage increase at the 5,000 threshold on budget variables. Terms from 1993 to 2001; only mayors observed for two terms, with binding term limit in the second. Estimates computed with Local Linear Regression (LLR) as in equation (8); the optimal symmetric bandwidth $\Delta$ is chosen with cross-validation methods. First robustness exercise: invariant town characteristics (Area in $\mathrm{km}^{2}$ and North/South dummy) as additional covariates. Second robustness exercise: sample restricted to mayors elected in contestable cities (i.e., with less than $55 \%$ of votes). Third robustness exercise: sample restricted to mayors elected for the first time after the 1993 reform. All variables are in per-capita terms, expressed in euros at 2000 prices, and averaged over the mayoral term (election years excluded). $T L$ is an index for the term limit. Standard errors robust to clustering at the municipality level are in parentheses. Significance at the $10 \%$ level is represented by *, at the $5 \%$ level by $* *$, and at the $1 \%$ level by ***. 
Table 13: Budget components per capita, placebo tests

\begin{tabular}{|c|c|c|c|c|c|c|c|c|c|}
\hline & \multirow[t]{2}{*}{ Deficit } & \multicolumn{4}{|c|}{ Expenditure } & \multicolumn{4}{|c|}{ Revenues } \\
\hline & & Total & Investments & $\begin{array}{c}\text { Personnel } \\
\text { and debt }\end{array}$ & $\begin{array}{c}\text { Goods and } \\
\text { services }\end{array}$ & Total & Transfers & Taxes & Tariffs \\
\hline & \multicolumn{9}{|c|}{ Split polynomial approximation, median above $(5,932)$} \\
\hline A. Overall $(\mathrm{TL}=0)$ & $\begin{array}{c}7.811 \\
(20.463)\end{array}$ & $\begin{array}{l}-160.051 \\
(228.821)\end{array}$ & $\begin{array}{c}-13.825 \\
(172.845)\end{array}$ & $\begin{array}{l}-21.167 \\
(69.780)\end{array}$ & $\begin{array}{c}-125.059 \\
(112.814)\end{array}$ & $\begin{array}{l}-167.863 \\
(228.685)\end{array}$ & $\begin{array}{c}-68.058 \\
(207.084)\end{array}$ & $\begin{array}{l}-74.455 \\
(68.814)\end{array}$ & $\begin{array}{l}-25.350 \\
(83.342)\end{array}$ \\
\hline B. Composition $(\mathrm{TL}=1)$ & $\begin{array}{c}11.548 \\
(12.891)\end{array}$ & $\begin{array}{l}-202.258 \\
(209.127)\end{array}$ & $\begin{array}{c}-4.351 \\
(99.392)\end{array}$ & $\begin{array}{l}-51.835 \\
(74.894)\end{array}$ & $\begin{array}{l}-146.071 \\
(92.317)\end{array}$ & $\begin{array}{l}-213.806 \\
(212.713)\end{array}$ & $\begin{array}{l}-85.559 \\
(159.264)\end{array}$ & $\begin{array}{l}-69.829 \\
(73.544)\end{array}$ & $\begin{array}{l}-58.418 \\
(68.603)\end{array}$ \\
\hline C. Incentive (A-B) & $\begin{array}{c}-3.736 \\
(19.959)\end{array}$ & $\begin{array}{c}42.206 \\
(193.491)\end{array}$ & $\begin{array}{c}-9.474 \\
(177.979)\end{array}$ & $\begin{array}{c}30.668 \\
(54.873)\end{array}$ & $\begin{array}{c}21.012 \\
(51.187)\end{array}$ & $\begin{array}{c}45.943 \\
(194.461)\end{array}$ & $\begin{array}{c}17.501 \\
(180.855)\end{array}$ & $\begin{array}{l}-4.626 \\
(38.430)\end{array}$ & $\begin{array}{c}33.068 \\
(49.339)\end{array}$ \\
\hline Obs. & 330 & 330 & 330 & 330 & 330 & 330 & 330 & 330 & 330 \\
\hline & \multicolumn{9}{|c|}{ Split polynomial approximation, median below $(3,980)$} \\
\hline A. Overall $(\mathrm{TL}=0)$ & $\begin{array}{c}17.094 \\
(12.782)\end{array}$ & $\begin{array}{c}149.264 \\
(134.936)\end{array}$ & $\begin{array}{c}146.787 \\
(100.112)\end{array}$ & $\begin{array}{c}44.621 \\
(36.201)\end{array}$ & $\begin{array}{l}-42.143 \\
(44.314)\end{array}$ & $\begin{array}{c}132.171 \\
(133.390)\end{array}$ & $\begin{array}{c}155.785 \\
(125.144)\end{array}$ & $\begin{array}{l}-39.932 \\
(43.435)\end{array}$ & $\begin{array}{c}16.317 \\
(46.820)\end{array}$ \\
\hline B. Composition $(\mathrm{TL}=1)$ & $\begin{array}{l}14.451 \\
(8.936)\end{array}$ & $\begin{array}{c}160.805 \\
(170.995)\end{array}$ & $\begin{array}{c}137.912 \\
(131.895)\end{array}$ & $\begin{array}{c}53.988 \\
(52.807)\end{array}$ & $\begin{array}{l}-31.094 \\
(45.590)\end{array}$ & $\begin{array}{c}146.354 \\
(170.626)\end{array}$ & $\begin{array}{c}180.280 \\
(170.028)\end{array}$ & $\begin{array}{l}-19.131 \\
(45.516)\end{array}$ & $\begin{array}{l}-14.795 \\
(32.712)\end{array}$ \\
\hline C. Incentive (A-B) & $\begin{array}{c}-3.154 \\
(13.711)\end{array}$ & $\begin{array}{l}-122.480 \\
(189.823)\end{array}$ & $\begin{array}{c}-90.121 \\
(184.674)\end{array}$ & $\begin{array}{l}-22.168 \\
(34.055)\end{array}$ & $\begin{array}{l}-10.191 \\
(32.993)\end{array}$ & $\begin{array}{l}-119.325 \\
(187.495)\end{array}$ & $\begin{array}{l}-122.282 \\
(187.477)\end{array}$ & $\begin{array}{l}-21.435 \\
(16.081)\end{array}$ & $\begin{array}{c}24.393 \\
(27.119)\end{array}$ \\
\hline Obs. & 666 & 666 & 666 & 666 & 666 & 666 & 666 & 666 & 666 \\
\hline
\end{tabular}

Notes. Estimated discontinuities in budget components at fake thresholds (i.e, median above and below the true 5,000 threshold). Terms from 1993 to 2001; only mayors observed for two terms, with binding term limit in the second. Estimates computed with a $3^{\text {rd }}$ order polynomial approximation on either side of the threshold as in equation (9). All variables are in per-capita terms, expressed in euros at 2000 prices, and averaged over the mayoral term (election years excluded). $T L$ is an index for the term limit. Standard errors robust to clustering at the municipality level are in parentheses. Significance at the $10 \%$ level is represented by $*$, at the $5 \%$ level by $* *$, and at the $1 \%$ level by $* * *$ 
Table 14: Efficiency measures, RDD estimates

\begin{tabular}{|c|c|c|}
\hline & $\begin{array}{l}\text { Speed of } \\
\text { collection }\end{array}$ & $\begin{array}{l}\text { Speed of } \\
\text { payments }\end{array}$ \\
\hline & \multicolumn{2}{|c|}{ LLR with optimal bandwidth } \\
\hline \multirow[t]{2}{*}{ A. Overall $(\mathrm{TL}=0)$} & $4.534^{*}$ & $1.636^{*}$ \\
\hline & $(2.482)$ & $(0.923)$ \\
\hline \multirow[t]{2}{*}{ B. Composition $(\mathrm{TL}=1)$} & 0.933 & 0.948 \\
\hline & $(2.742)$ & $(1.011)$ \\
\hline \multirow[t]{2}{*}{ C. Incentive (A-B) } & 3.601 & 0.688 \\
\hline & $(3.597)$ & $(1.066)$ \\
\hline$\Delta$ & 900 & 1,500 \\
\hline \multirow{2}{*}{ Obs. } & 624 & 1,016 \\
\hline & \multicolumn{2}{|c|}{ LLR with half optimal bandwidth } \\
\hline \multirow[t]{2}{*}{ A. Overall $(\mathrm{TL}=0)$} & $5.565^{*}$ & 0.989 \\
\hline & $(3.217)$ & $(1.253)$ \\
\hline \multirow[t]{2}{*}{ B. Composition $(\mathrm{TL}=1)$} & -1.472 & 1.256 \\
\hline & $(4.378)$ & $(1.479)$ \\
\hline \multirow[t]{2}{*}{ C. Incentive (A-B) } & 7.037 & -0.267 \\
\hline & $(5.135)$ & $(1.406)$ \\
\hline$\Delta$ & 450 & 750 \\
\hline \multirow[t]{2}{*}{ Obs. } & 328 & 510 \\
\hline & \multicolumn{2}{|c|}{ Split polynomial approximation } \\
\hline \multirow[t]{2}{*}{ A. Overall $(\mathrm{TL}=0)$} & $6.207^{*}$ & 0.986 \\
\hline & $(3.279)$ & $(1.661)$ \\
\hline \multirow[t]{2}{*}{ B. Composition $(\mathrm{TL}=1)$} & -1.604 & 0.747 \\
\hline & $(4.169)$ & (1.987) \\
\hline \multirow[t]{2}{*}{ C. Incentive (A-B) } & 7.811 & 0.238 \\
\hline & $(5.002)$ & $(1.819)$ \\
\hline Obs. & 1,194 & 1,194 \\
\hline
\end{tabular}

Notes. Effect of the $33 \%$ wage increase at the 5,000 threshold on efficiency measures. Terms from 1993 to 2001; only mayors observed for two terms, with binding term limit in the second. First estimate: Local Linear Regression (LLR) as in equation (8); the optimal symmetric bandwidth $\Delta$ is chosen with cross-validation methods. Second estimate: LLR with half optimal bandwidth. Third estimate: $3^{\text {rd }}$ order polynomial approximation on either side of the threshold as in equation (9); the maximum symmetric bandwidth is 1,750. The Efficiency measures are expressed in percentage points: Speed of collection is the ratio between collected and assessed revenues; Speed of payment is the ratio between paid and committed outlays for public expenditure. $T L$ is an index for the term limit. Standard errors robust to clustering at the municipality level are in parentheses. Significance at the $10 \%$ level is represented by *, at the $5 \%$ level by **, and at the $1 \%$ level by ***. 
Table 15: Efficiency measures, robustness exercises

\begin{tabular}{|c|c|c|}
\hline & $\begin{array}{l}\text { Speed of } \\
\text { collection }\end{array}$ & $\begin{array}{l}\text { Speed of } \\
\text { payments }\end{array}$ \\
\hline & \multicolumn{2}{|c|}{$\begin{array}{c}\text { LLR with optimal bandwidth } \\
\text { for contestable cities }\end{array}$} \\
\hline A. Overall $(\mathrm{TL}=0)$ & $\begin{array}{c}3.963 \\
(2.639)\end{array}$ & $\begin{array}{c}1.076 \\
(1.164)\end{array}$ \\
\hline B. Composition $(\mathrm{TL}=1)$ & $\begin{array}{l}1.545 \\
(2.506)\end{array}$ & $\begin{array}{c}0.662 \\
(1.279)\end{array}$ \\
\hline C. Incentive (A-B) & $\begin{array}{c}2.417 \\
(3.386)\end{array}$ & $\begin{array}{c}0.414 \\
(1.386)\end{array}$ \\
\hline$\Delta$ & 1,600 & 1,600 \\
\hline Obs. & 647 & 647 \\
\hline & \multicolumn{2}{|c|}{$\begin{array}{l}\text { LLR with optimal bandwidth } \\
\text { for freshmen after } 1993\end{array}$} \\
\hline A. Overall $(\mathrm{TL}=0)$ & $\begin{array}{c}4.882 \\
(3.072)\end{array}$ & $\begin{array}{l}1.338 \\
(1.115)\end{array}$ \\
\hline B. Composition $(\mathrm{TL}=1)$ & $\begin{array}{l}1.086 \\
(3.117)\end{array}$ & $\begin{array}{c}1.284 \\
(1.301)\end{array}$ \\
\hline C. Incentive (A-B) & $\begin{array}{c}3.796 \\
(4.321)\end{array}$ & $\begin{array}{c}0.054 \\
(1.322)\end{array}$ \\
\hline$\Delta$ & 900 & 1,300 \\
\hline Obs. & 494 & 696 \\
\hline & \multicolumn{2}{|c|}{$\begin{array}{c}\text { LLR with optimal bandwidth } \\
\text { and covariates }\end{array}$} \\
\hline A. Overall $(\mathrm{TL}=0)$ & $\begin{array}{l}4.756^{*} \\
(2.468)\end{array}$ & $\begin{array}{c}1.423 \\
(0.899)\end{array}$ \\
\hline B. Composition $(\mathrm{TL}=1)$ & $\begin{array}{c}0.869 \\
(2.603)\end{array}$ & $\begin{array}{c}0.657 \\
(1.021)\end{array}$ \\
\hline C. Incentive (A-B) & $\begin{array}{c}3.626 \\
(3.605)\end{array}$ & $\begin{array}{c}0.687 \\
(1.067)\end{array}$ \\
\hline$\Delta$ & 900 & 1,500 \\
\hline Obs. & 624 & 1,016 \\
\hline
\end{tabular}

Notes. Effect of the 33\% wage increase at the 5,000 threshold on efficiency measures. Terms from 1993 to 2001; only mayors observed for two terms, with binding term limit in the second. Estimates computed with Local Linear Regression (LLR) as in equation (8); the optimal symmetric bandwidth $\Delta$ is chosen with cross-validation methods. First robustness exercise: invariant town characteristics (Area in $\mathrm{km}^{2}$ and North/South dummy) as additional covariates. Second robustness exercise: sample restricted to mayors elected in contestable cities (i.e., with less than $55 \%$ of votes). Third robustness exercise: sample restricted to mayors elected for the first time after the 1993 reform. The Efficiency measures are expressed in percentage points: Speed of collection is the ratio between collected and assessed revenues; Speed of payment is the ratio between paid and committed outlays for public expenditure. $T L$ is an index for the term limit. Standard errors robust to clustering at the municipality level are in parentheses. Significance at the $10 \%$ level is represented by ${ }^{*}$, at the $5 \%$ level by ${ }^{* *}$, and at the $1 \%$ level by $* * *$. 
Table 16: Efficiency measures, placebo tests

\begin{tabular}{|c|c|c|}
\hline & $\begin{array}{l}\text { Speed of } \\
\text { collection }\end{array}$ & $\begin{array}{l}\text { Speed of } \\
\text { payments }\end{array}$ \\
\hline & \multicolumn{2}{|c|}{$\begin{array}{c}\text { Split polynomial approximation } \\
\text { median above }(5,932)\end{array}$} \\
\hline A. Overall $(\mathrm{TL}=0)$ & $\begin{array}{l}2.208 \\
(5.098)\end{array}$ & $\begin{array}{c}4.102 \\
(3.425)\end{array}$ \\
\hline B. Composition $(\mathrm{TL}=1)$ & $\begin{array}{l}-0.823 \\
(7.891)\end{array}$ & $\begin{array}{c}0.827 \\
(3.656)\end{array}$ \\
\hline C. Incentive (A-B) & $\begin{array}{c}3.031 \\
(9.314)\end{array}$ & $\begin{array}{c}3.274 \\
(3.336)\end{array}$ \\
\hline Obs. & 330 & 330 \\
\hline & \multicolumn{2}{|c|}{$\begin{array}{c}\text { Split polynomial approximation } \\
\text { median below }(3,980)\end{array}$} \\
\hline A. Overall $(\mathrm{TL}=0)$ & $\begin{array}{c}1.589 \\
(5.313)\end{array}$ & $\begin{array}{l}-1.507 \\
(2.076)\end{array}$ \\
\hline B. Composition $(\mathrm{TL}=1)$ & $\begin{array}{l}-3.825 \\
(3.661)\end{array}$ & $\begin{array}{l}-2.125 \\
(2.181)\end{array}$ \\
\hline C. Incentive (A-B) & $\begin{array}{c}4.068 \\
(6.203)\end{array}$ & $\begin{array}{c}0.042 \\
(2.187)\end{array}$ \\
\hline Obs. & 666 & 666 \\
\hline
\end{tabular}

$\overline{\text { Notes. Estimated discontinuities in efficiency measures at fake thresholds (i.e, median }}$ above and below the true 5,000 threshold). Terms from 1993 to 2001; only mayors observed for two terms, with binding term limit in the second. Estimates computed with a $3^{\text {rd }}$ order polynomial approximation on either side of the threshold as in equation (9). The Efficiency measures are expressed in percentage points: Speed of collection is the ratio between collected and assessed revenues; Speed of payment is the ratio between paid and committed outlays for public expenditure. $T L$ is an index for the term limit. Standard errors robust to clustering at the municipality level are in parentheses. Significance at the $10 \%$ level is represented by *, at the $5 \%$ level by $* *$, and at the $1 \%$ level by $* * *$. 
Figure 1: Population distribution $(<20,000)$

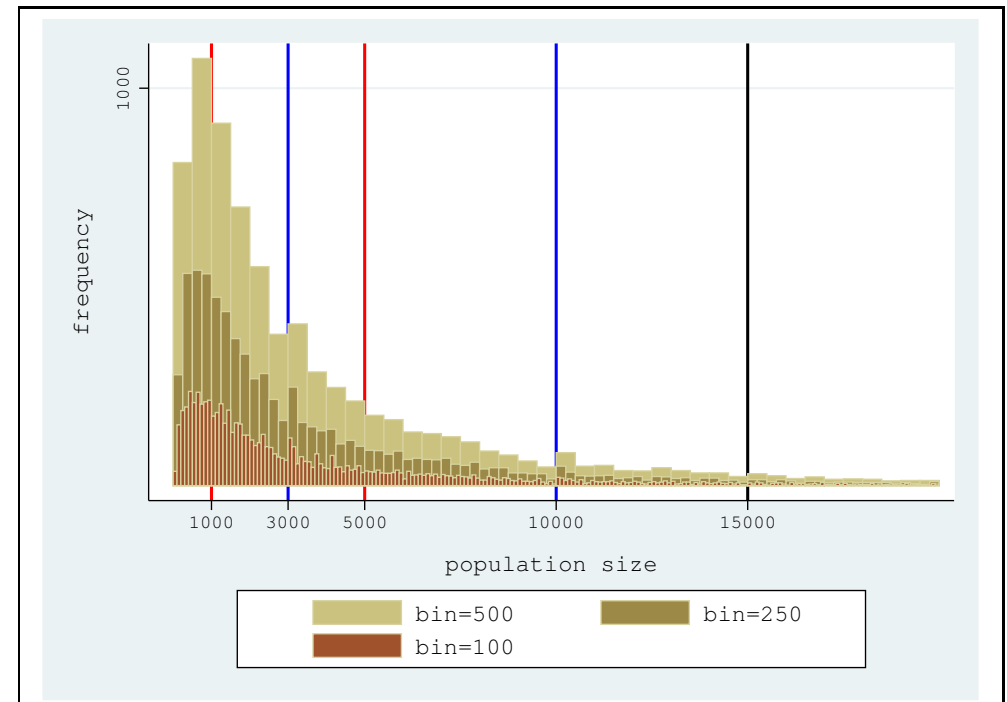

Notes. Frequency of cities according to population in the 2001 Census. Cities below 20,000 inhabitants only. Vertical lines identify policy thresholds.

Figure 2: Population density around the 5,000 threshold

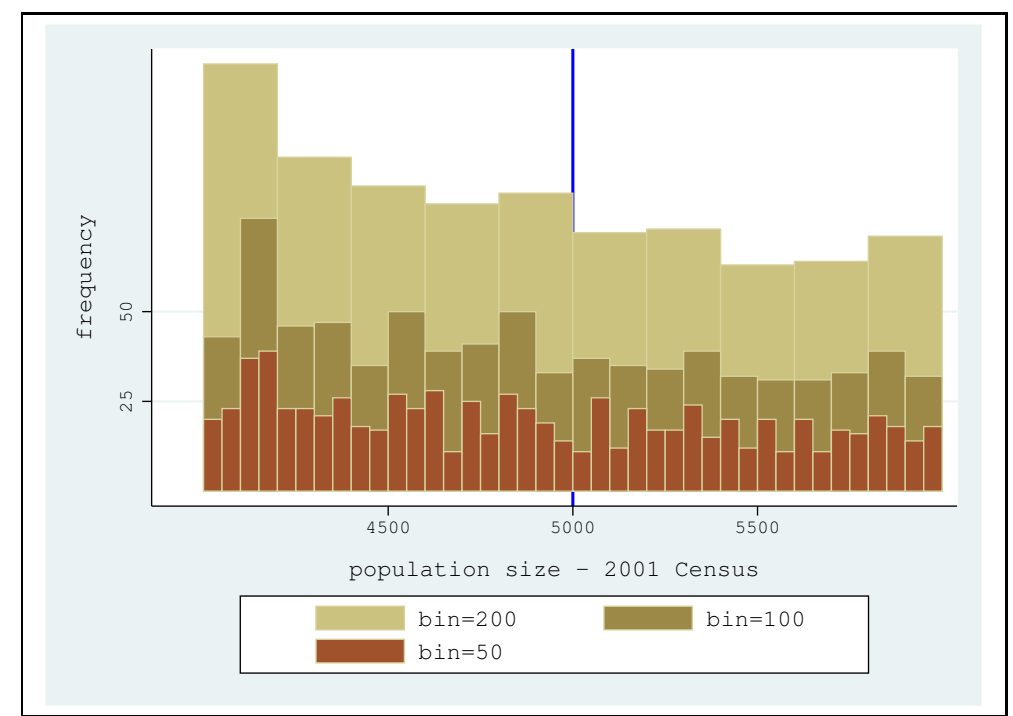

Notes. Frequency of cities around the 5,000 threshold (vertical line), according to population size in the 2001 Census. 
Figure 3: McCrary test

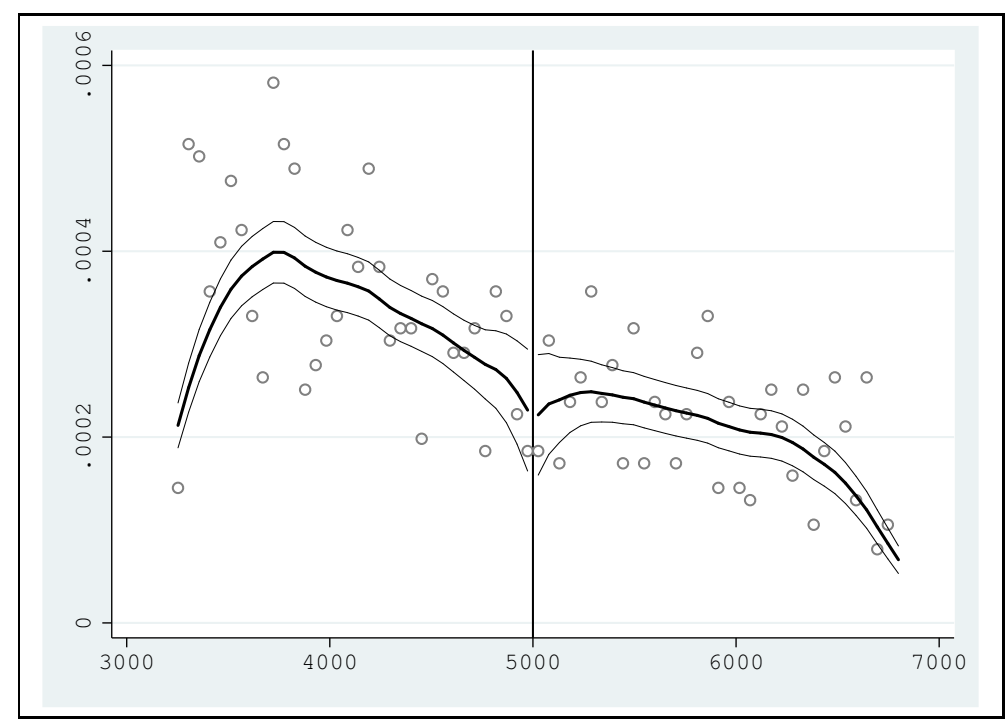

Notes. Weighted kernel estimation of the log density (according to the 2001 Census), performed separately on either side of the 5,000 threshold. Optimal binwidth and binsize as in McCrary (2008).

Figure 4: Candidate characteristics around the 5,000 threshold

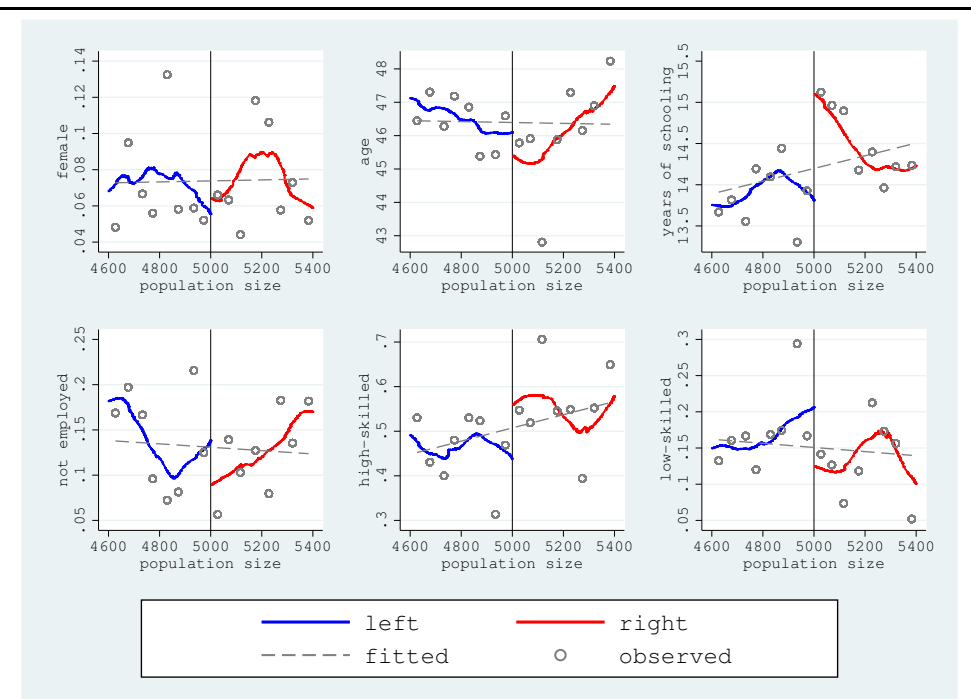

Notes. The solid line is a running-mean smoothing of the variable on the vertical axis (with a bandwidth of 1), performed separately on either side of the 5,000 threshold. The dash line is a fitted regression over the whole sample. The dots are the observed values averaged in intervals of 50 inhabitants. 
Figure 5: Mayor characteristics around the 5,000 threshold

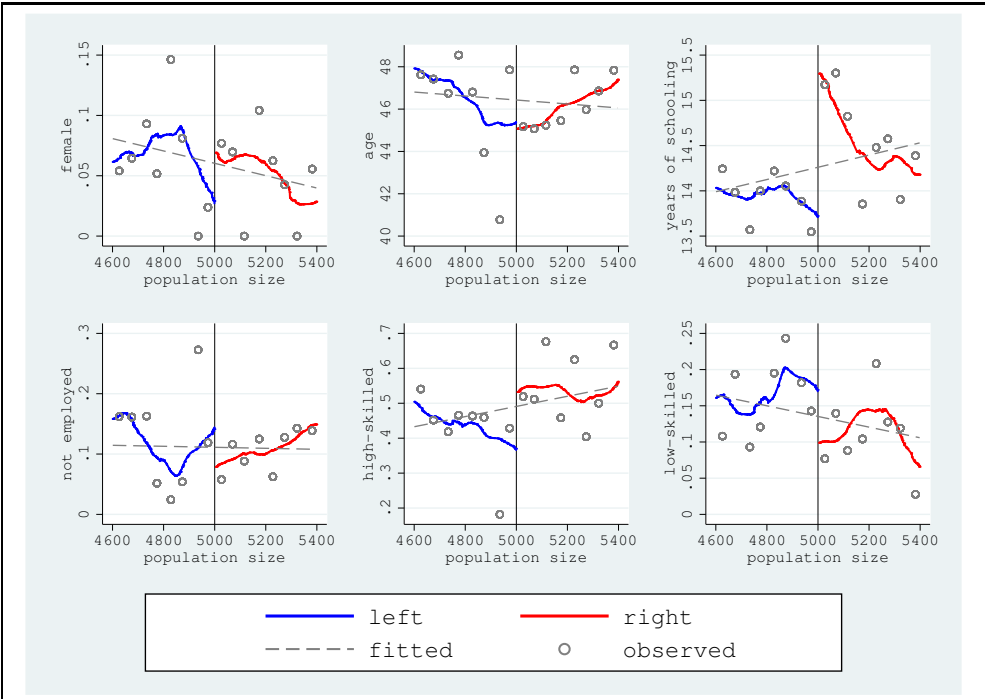

Notes. The solid line is a running-mean smoothing of the variable on the vertical axis (with a bandwidth of 1), performed separately on either side of the 5,000 threshold. The dash line is a fitted regression over the whole sample. The dots are the observed values averaged in intervals of 50 inhabitants.

Figure 6: Budget components (per capita) around the 5,000 threshold

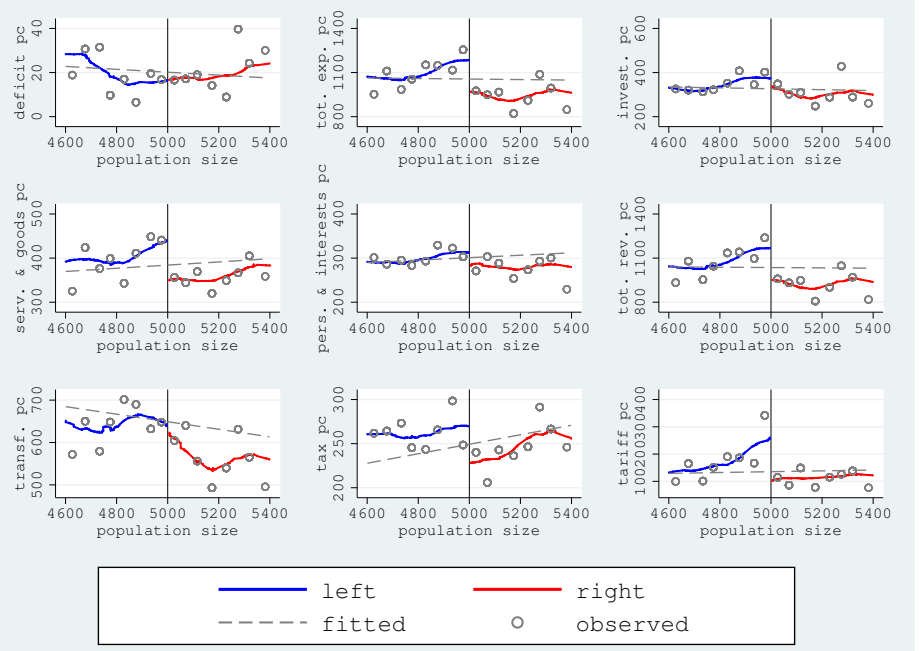

Notes. The solid line is a running-mean smoothing of the variable on the vertical axis (with a bandwidth of 1 ), performed separately on either side of the 5,000 threshold. The dash line is a fitted regression over the whole sample. The dots are the observed values averaged in intervals of 50 inhabitants. 
Figure 7: Efficiency measures around the 5,000 threshold

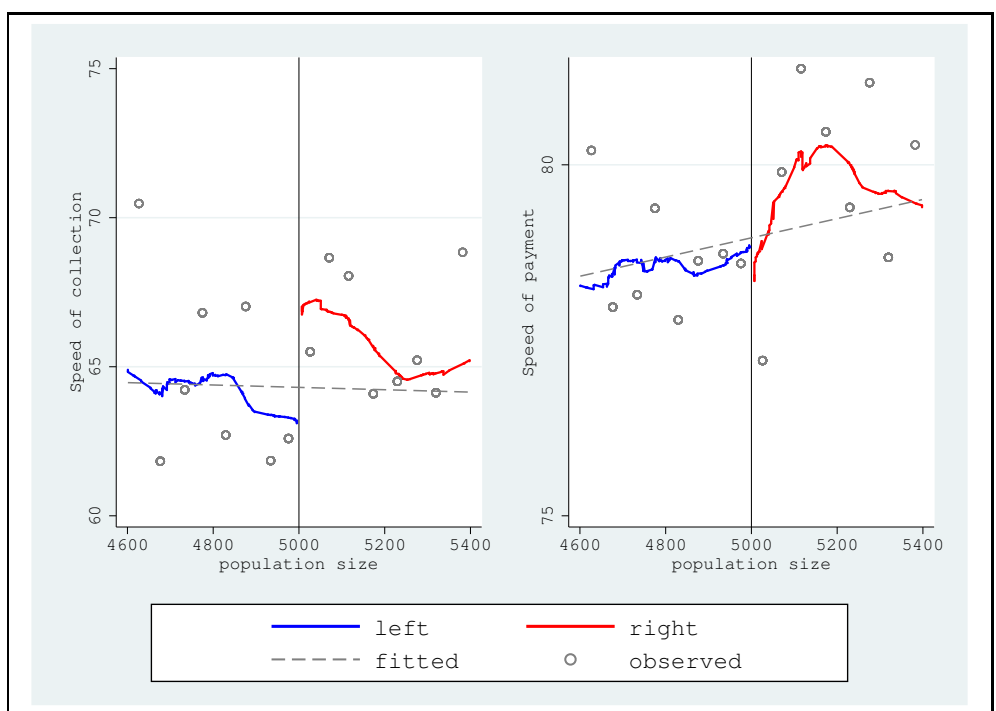

Notes. The solid line is a running-mean smoothing of the variable on the vertical axis (with a bandwidth of 1), performed separately on either side of the 5,000 threshold. The dash line is a fitted regression over the whole sample. The dots are the observed values averaged in intervals of 50 inhabitants. 